\title{
Do Short-Term Incentives Affect Long-Term \\ Productivity?
}

by

\author{
Heitor Almeida \\ University of Illinois at Urbana-Champaign and NBER \\ Nuri Ersahin \\ Michigan State University \\ Vyacheslav Fos \\ Boston College, CEPR, and ECGI \\ Rustom M. Irani \\ University of Illinois at Urbana-Champaign and CEPR \\ Mathias Kronlund \\ University of Illinois at Urbana-Champaign
}

\begin{abstract}
CES 20-10
March, 2020

The research program of the Center for Economic Studies (CES) produces a wide range of economic analyses to improve the statistical programs of the U.S. Census Bureau. Many of these analyses take the form of CES research papers. The papers have not undergone the review accorded Census Bureau publications and no endorsement should be inferred. Any opinions and conclusions expressed herein are those of the author(s) and do not necessarily represent the views of the U.S. Census Bureau. All results have been reviewed to ensure that no confidential information is disclosed. Republication in whole or part must be cleared with the authors.

To obtain information about the series, see www.census.gov/ces or contact Christopher Goetz, Editor, Discussion Papers, U.S. Census Bureau, Center for Economic Studies 5K038E, 4600 Silver Hill Road, Washington, DC 20233, CES.Working.Papers@census.gov. To subscribe to the series, please click here.
\end{abstract}




\begin{abstract}
Previous research shows that stock repurchases that are caused by earnings management lead to reductions in firm-level investment and employment. It is natural to expect firms to cut less productive investment and employment first, which could lead to a positive effect on firm-level productivity. However, using Census data, we find that firms make cuts across the board irrespective of plant productivity. This pattern seems to be associated with frictions in the labor market. Specifically, we find evidence that unionization of the labor force may prevent firms from doing efficient downsizing, forcing them to engage in easy or expedient downsizing instead. As a result of this inefficient downsizing, EPS-driven repurchases lead to a reduction in long-term productivity.
\end{abstract}

Keyword: roductivity, Employment, Labor unions, Investment, Short-termism, Share repurchases

JEL Classification: G32, G35, J23

\footnotetext{
* Heitor Almeida is at the University of Illinois at Urbana-Champaign; 1206 South Sixth Street; Cham-paign, IL, 61820; U.S.A.; Email: halmeida@illinois.edu. Phone: (217) 333-2704. Nuri Ersahin is at Michigan State University; 632 Bogue St; East Lansing, MI 48824; U.S.A.; Email: ersahin2@msu.edu. Phone: (517) 353-1705. Vyacheslav Fos is at Boston College; 140 Commonwealth Avenue; Chestnut Hill, MA 02467; U.S.A.; Email: fos@bc.edu. Phone: (617) 552-1536. Rustom M. Irani is at the University of Illinois at Urbana-Champaign; 1206 South Sixth Street; Champaign, IL, 61820; U.S.A.; Email: rirani@illinois.edu. Phone: (217) 300-0472. Mathias Kronlund is at the University of Illinois at Urbana-Champaign; 1206 South Sixth Street; Champaign, IL, 61820; U.S.A.; Email: kronlund@illinois.edu. Phone: (217) 244-2631. The research in this article was conducted while the authors were Special Sworn Status researchers of the U.S. Census Bureau at the Chicago Census Research Data Center. We are also very grateful to Frank Limehouse and Lanwei Yang at the Chicago and UIUC Census Research Data Centers, respectively, for their ongoing assistance. Any opinions and conclusions expressed herein are those of the authors and do not necessarily represent the views of the U.S. Census Bureau. All results have been reviewed to ensure that no confidential information is disclosed.
} 


\section{Introduction}

Are US companies short-termist? Several recent papers identify actions that indicate short-termism, such as a reduction in long-term investment due to vesting equity Edmans et al., 2017; Ladika and Sautner, 2018), and a reduction in R\&D growth that allows firms to meet earnings forecasts (Terry, 2017). The short-termist hypothesis also implies that these actions should hurt firms and the economy in the long-run. However, there is limited evidence on the effects of short term incentives on firms' long-run productivity and performance. This paper attempts to fill this gap.

Specifically, we study the long-term effects of the incentive to engage in repurchases in order to meet short-term performance targets (EPS-driven repurchases). Hribar et al. (2006) and Almeida, Fos, and Kronlund (2016) show that firms that are just about to miss the consensus earnings-per-share (EPS) forecast have significantly higher repurchases than firms that just meet the EPS forecast without conducting repurchases. Almeida et al. (2016) also show a similar discontinuity in the growth of capital expenditures, employment, and R\&D, which suggests that managers are willing to trade-off investments and employment for stock repurchases that allow them to meet analyst EPS forecasts. While this behavior is indicative of short-termism, it is not clear whether it leads to a deterioration of firms'

productivity in the long-run. On the contrary, one might expect firms to cut their less productive investments, which would not result in any adverse effect on the firm's overall productivity.

To shed further light on this question, it is crucial to look more closely into the characteristics of investments that get cut because of incentives to engage in EPS-driven repurchases. Are firms making cuts across the board, or are firms cutting less productive investments first? To answer this question, we use census data. These data allow us to examine changes in resource allocation and productivity at the plant level, and study how pre-existing plant 
characteristics are related to cuts due to these short-term incentives. Our identification strategy follows that in Almeida et al. (2016), which exploits a discontinuity in incentives to engage in repurchases when managers expect to just miss the analyst consensus EPS forecast. The key identification assumption behind this empirical strategy is that in the absence of a discontinuous jump in the incentive to repurchase around zero (pre-repurchase) EPS surprises, there are no other discontinuous changes in firm policies that directly affect outcome variables such as investments and long-term productivity (see Section 2.2 for further discussion). Under this identification assumption, our tests measure the effect of incentive to engage in stock repurchases in order to meet short-term performance targets on investments and productivity.

We begin by replicating the main results in Almeida et al. (2016) using census data. Consistent with that paper, we observe a significant decline in investment and employment expenditures in plants that belong to firms that have incentives to invest resources to boost short-term performance measures (those just to the left of the pre-repurchase zero EPS surprise).

Next, we focus on changes in total factor productivity (TFP), measured using the difference in TFP three years before to three years after the quarter in which we measure incentives to engage in EPS-driven repurchases. We find that firms with stronger incentives to engage in EPS-driven repurchases experience a significant deterioration in average productivity across its plants. In particular, firm-level TFP falls by about $1.4 \%$. Thus, we find that stronger incentives to boost short-term performance lead to cuts in investments and employment as well as a drop in firm-level productivity.

We then investigate the reasons why EPS-driven repurchases may lead to a drop in firm-level TFP. First, we study whether cuts in investment and employment depend on the plant's productivity. It would be natural to expect that cuts in investment and employment are concentrated in relatively unproductive plants. However, we find evidence that firms 
make cuts across the board, irrespective of plant productivity. ${ }^{1}$ Specifically, we find that while cuts in employment are stronger for unproductive plants than for productive plants, firms appear to cut investment uniformly across productive and unproductive plants.

Importantly, we present evidence that this apparently inefficient reallocation of resources is at least partly a consequence of frictions in the labor market. Specifically, we investigate whether cuts in employment and investment are similar in states that have and have not adopted right-to-work (RTW) legislation. Labor unions may act as an impediment to doing relatively more efficient cuts, to the extent that labor rules constrain a firm's actions (e.g., Chava et al., 2018; Serfling, 2016). Consistent with this hypothesis, we find that for plants located in RTW states (where the labor force is less organized), the only significant cuts are observed for employment in unproductive units, but we do not find significant cuts in investment across any type of plant, whether productive or unproductive, in these states. Moreover, we find no significant changes in employment in productive plants. These findings contrast with those for plants located in non-RTW states. Among the plants in these states with higher union power, firms make significant cuts in employment and investment not only for unproductive plants but also for productive plants. Thus, unionization of the labor force may prevent firms from doing efficient downsizing, which thereby enhances the negative long-term consequences of incentives to boost short-term performance.

Since labor unionization is more likely to cover production workers, we next investigate whether changes in employment are similar for production and non-production workers. Production workers are employees (up through the working foreman level) engaged in production operations at the plant. Non-production personnel includes supervisors (above foreman level) and office employees in sales and marketing, financing, purchasing, professional and technical. We find that for plants located in RTW states, significant cuts in employment are

\footnotetext{
${ }^{1}$ In our main tests, plants are classified as "productive" and "unproductive" on the basis of their withinfirm TFP ranking. In robustness tests, we also consider within-industry rankings of plants, as well as several nonparametric measures of productivity.
} 
observed for all types of employees in unproductive units. In contrast, for plants located in non-RTW states, cuts in production employees are weaker for productive plants, supporting the protection granted by unionization. These results support the hypothesis that the unionization of the labor force may be the reason why firms engage in inefficient reallocation when faced with short-term pressures to downsize.

Our findings suggest that plants located in non-RTW states experience less efficient cuts than plants located in RTW states, indicating that union power adversely affects the reallocation of resources. Do these differences lead to the negative changes in productivity? To examine this hypothesis, we investigate whether changes in firm-level productivity depend on the fraction of the firm's business located in non-RTW states. Our results do suggest that the reduction in TFP that is engendered by short-term incentives is concentrated in firms that have significant business in non-RTW states (strong labor unions). Firms with weaker labor unions undertake more efficient cuts, and thus experience no significant deterioration in firm productivity.

Overall, our evidence suggests that short term incentives lead to lower long-term productivity, but only if there are additional frictions that prevent firms from downsizing in an efficient manner. Firms that have incentives to engage in repurchases to meet EPS forecasts subsequently reduce investment and employment. If firms have most of their plants in states in which labor is weak, the bulk of the adjustment happens in unproductive plants, which minimizes the impact of the downsizing on productivity. But if their plants are located in states in which labor is strong, unionization of the labor force prevents firms from efficiently downsizing. These firms make cuts across the board, even in productive plants. As a result of this adjustment, productivity goes down in the long run.

This paper contributes to the growing literature on the real effects of short-termism. Philippon and Gutierrez (2017) suggest that short-termism due to the increase in institutional ownership and the rise in investor activism contributed to the drop in long-term 
investment after the early 2000s documented in their paper. However, empirical evidence does not support the claim that investor activism leads to short-termism. Instead, the evidence in papers such as Brav et al. (2015), Brav et al. (2018), and Bebchuk et al. (2015) broadly suggests that activists increase long-term performance at the companies that they target. Kaplan (2018) also notes that there is little evidence that short-termism has affected long-term profits. In contrast to these results, our paper shows evidence that short-term incentives do lead to lower long-term productivity for some firms.

Our results are consistent with other recent papers that identify actions that indicate short-termism, such as a reduction in long-term investment due to vesting equity Edmans et al., 2017; Ladika and Sautner, 2018), and a reduction in R\&D growth that allows firms to meet earnings forecasts Terry (2017). This literature also suggests that short-term incentives can lead to long-term underperformance. Ladika and Sautner (2018) find that firms that go through option vesting acceleration underperform in the long term, and especially so when they cut investments. The increase in R\&D volatility due to EPS targets can lead to lower growth and welfare losses that are of similar magnitude as those engendered by business cycles, trade barriers, or inflation, in a standard growth model (Terry, 2017). Our paper contributes to this literature by presenting evidence that short-termism affects firm-level productivity, and identifying conditions under which this effect occurs.

Finally, our paper is consistent with earlier literature that suggests that chasing EPS targets is a driver of short-termism. Graham et al. (2005), for example, report survey evidence that CFOs are willing to take real economic actions, such as decreasing discretionary spending or delaying a new project, to meet EPS targets. Our paper shows that such actions can have significant long-term consequences for firms. 


\section{$2 \quad$ Data and Empirical Strategy}

\subsection{Data}

This section describes our data sample and variable construction.

Establishment-level data are provided by the U.S. Census Bureau. Our primary data sources are the Census of Manufactures (CMF) and the Annual Survey of Manufactures (ASM). These two data products provide highly-granular information on the economic activity of manufacturing establishments ("plants"). Manufacturing plants have NAICS codes between 3111 and 3399. The CMF is a survey conducted every five years (years ending 2 and 7) and consists of all manufacturing establishments in the United States with at least one paid employee. The ASM is another survey conducted in non-census years (i.e., when the CMF is not conducted) for a subset of these manufacturing plants. This includes all plants with greater than 250 employees and some with fewer employees, which are selected with a probability positively correlated with size. Reporting for both of these surveys is mandatory and misreporting is penalized, so the data is of the highest quality. Both the CMF and ASM include information on location, industry, corporate affiliation, output (total value of shipments), employment, capital expenditures, and on material inputs of each plant. The level of detail of these manufacturing data sets helps us measure factor inputs and construct various measures of productivity for each manufacturing plant.

Our firm-level data comes from CRSP/Compustat. This database contains stock prices, balance sheet, and income statement data for publicly traded U.S. corporations, which are the focus of this study. We collect repurchase, stock price, and earnings data required to calculate the repurchase-adjusted earnings per share, as described below. We also extract standard accounting variables primarily to be used as control variables in our regression analysis. We use the Compustat-SSEL bridge maintained by the Census to match each Compustat firm to its manufacturing plants. The Compustat-SSEL bridge ends in 2011, so 
we extend the match to 2013 using employer characteristics, including name, address, and employer identification number.

We capture how firms allocate resources using employment and investment data from the CMF/ASM. In most tests, employment is measured as the three-year average change in employment expenditures (salaries and wages, i.e., payroll) scaled by the lagged plant-level capital stock. Plant-level capital stock is estimated using the perpetual inventory method following Brav et al. (2015), and described in detail in Ersahin (2018). At the firm level, employment expenditures are summed across all of the firm's plants.

In some tests, we separately examine production and non-production workers. Production workers are employees (up through the working foreman level) engaged in production operations at the plant. Non-production personnel includes supervisors (above the working foreman level) and office employees in sales and marketing, financing, purchasing, professional and technical.

We consider two additional employment measures for robustness. First, the change in the natural logarithm of the number of employees. Second, the symmetric growth rate of employment, calculated by dividing the three-year average change in the number of employees by the average of this change and lagged number of employees. This measure accommodates both entry and exit as well as limiting the effects of extreme values (Davis et al., 1998).

Alongside employment, we also analyze changes in investment. We calculate investment as the three-year average change in plant-level capital expenditures scaled by the lagged plant-level capital stock. For robustness, we also consider plant-level expenditures on new machinery equipment. As with employment, firm-level investment is calculated by aggregating across plants.

We measure plant productivity as the natural logarithm of total factor productivity 
(TFP) following the methodology of Foster et al. (2016). In particular, TFP is given by:

$$
T F P_{i t}=\ln Q_{i t}-\alpha_{k t} \ln K_{i t}-\alpha_{l t} \ln L_{i t}-\alpha_{m t} \ln M_{i t}
$$

where $i$ and $t$ index plants and years, respectively. The variables TFP, $Q, K, L, M$, and $\alpha$ represent total factor productivity, real output, capital stock, labor input, cost of materials and parts, and factor elasticities. We measure output as the sum of the plant's total value of shipments and the change in inventories for finished goods and work-in-progress. We obtain real output by deflating output using industry-level prices provided by the NBERCES Manufacturing Industry Database.

We also analyze operating margins, as well as individual labor and capital productivities. The operating margin is measured by scaling the total value of shipments minus labor and material costs by the total value of shipments. The advantage of operating margin is that it does not require any structural assumptions, such as a Cobb-Douglas production function. We measure labor productivity following Brav et al. (2015) as the natural logarithm of value added per labor hour, which is calculated as the total value of shipments minus material and energy costs divided by total labor hours. Capital productivity is measured by return on capital (ROC), which is calculated as the total value of shipments minus labor, material, and energy costs scaled by capital stock. All inputs are measured in 1997 dollars.

We construct a final sample containing 6,700 firm-year observations covering approximately 69,000 plant-years for the period from 1988 until 2010. Table I presents summary statistics for the full sample. The table also partitions the sample according to whether firms have slightly positive or negative pre-repurchase EPS surprises (Panel A) and depending on the firm's presence in states with right-to-work laws in place (Panel B). ${ }^{2}$

${ }^{2}$ As per Census disclosure requirements, we round off the number of observations in each table and quantile values are not reported in any summary statistics table. 


\section{$2.2 \quad$ Empirical strategy}

This paper studies how the incentive to engage in EPS-driven share repurchases affects future resource allocation and firm productivity. Two important empirical challenges are involved when studying this question. First, identifying and measuring short-termist behavior is challenging; in other words, how might an outside observer know if a particular action that is taken by the firm indeed is motivated by short-termist pressures? The setting of using EPS-driven share repurchases offers a compelling setting precisely because spending money on buybacks in order to just meet or beat an EPS target is an identifiable example of such incentives. Second, actions that firms take to respond to short-termist pressures, such as EPS-driven repurchases, may be endogenous and thus confounded by omitted variables or selection. Identifying the counterfactual of what would have happened to the firm in the absence of such actions is challenging.

Our baseline approach of identifying plausibly causal effects on firms' productivity and resource allocation follows the "fuzzy regression discontinuity" framework of Almeida et al. (2016). The basic idea is that firms have a strong incentive to meet or beat their quarterly EPS consensus, and firms can use stock repurchases to raise their EPS to do so. We start by constructing a variable, pre-repurchase EPS surprise, which captures what the firm's EPS would have been if it did not engage in any buybacks, and show that firms that fall just below the zero-threshold are more likely to engage in share repurchases. ${ }^{3}$ We then use this discontinuity in the incentive to engage in EPS-driven repurchases to study the effects on future firm outcomes.

To understand the discontinuity, consider the following example. Suppose that the analyst EPS consensus forecast is $\$ 3.00$ a share, and that the company has one billion shares outstanding. A manager learns that the actual reported EPS number is going to be $\$ 2.99$ a share. The manager can meet the forecast by increasing share repurchases. For example,

\footnotetext{
${ }^{3}$ This discontinuity is originally documented by Hribar et al. (2006)
} 
using $\$ 600$ million to repurchase stock at an assumed price of $\$ 60$ per share would reduce shares outstanding to 990 million. The company's earnings would also tend to decrease because the company forgoes interest payments on its cash holdings. Assuming, for example, that the interest rate is $5 \%$, the firm's marginal tax rate is $30 \%$, and the company forgoes one quarter of interest, the forgone interest is $1.25 \% *(1-30 \%) * \$ 600$ million $=\$ 5.25$ million. Thus, total earnings would decrease from $\$ 2.99$ billion to $\$ 2.98475$ billion, resulting in a new EPS equal to $\$ 3.01$ (rounded to the nearest cent). This example illustrates how firms can move from a pre-repurchase EPS of $\$ 2.99$ to an actual EPS of $\$ 3.01$, or equivalently, moving the EPS surprise (relative to the analyst consensus) from -1 cent to +1 cent. Note that the required repurchases are economically meaningful: changing EPS by just two cents involves spending cash representing $1 \%$ of the firm's equity value - this is more than four times larger than firms' average quarterly repurchases in our sample.

To capture the causal effect of the incentive to engage in EPS-driven stock repurchases on outcome variables, we estimate the following regression:

$$
\begin{aligned}
& Y_{i t}=\alpha+\beta_{1} I_{\text {Negative }} \text { Sue }_{a d j}, i t+\beta_{2} S u e_{a d j, i t} \\
& +\beta_{3} S_{\text {Sue }} \text { adj,it }_{\text {Negative }} I_{\text {Sue }}{ }_{\text {adj }, i t}+\beta_{4} X_{i t}+\eta_{i}+\theta_{t}+\epsilon_{i t} .
\end{aligned}
$$

$Y_{i t}$ is outcome variable of interest for firm $i$ (or plant $i$ in our plant-level analysis) in quarter $t$. When we study future firm outcomes, we will define this variable as a difference between the three-year future outcome (such as firm or plant productivity) and the lagged outcome. $S u e_{a d j}$ is the pre-repurchase EPS surprise, $I_{\text {Negative }}$ Sue $_{a d j}$ is an indicator of having a negative pre-repurchase EPS surprise, $X$ is a vector of controls (an indicator of whether the firm paid a dividend in the previous year, ROA, quarterly stock returns, and the ratio of cash to assets), $\eta_{i}$ are firm fixed effects, and $\theta_{t}$ are year-quarter fixed effects. The exact formula used to calculate the pre-repurchase EPS surprise is described in Fig. A.1. To isolate any 
differences around the threshold, we limit the sample throughout to a small window around a zero pre-repurchase EPS surprise, $-0.003 \leq S u e_{a d j} \leq 0.003$.

The key identification assumption behind this empirical strategy is as follows: in the absence of a discontinuous jump in the incentive to repurchase around zero pre-repurchase EPS surprises, there are no other discontinuous changes in firm policies around zero prerepurchase EPS surprises that directly affect our outcome variables. Our specification controls for time-invariant observable or unobservable characteristics, as our main variables are defined using differences between future and lagged outcomes. Because we control for the level of the earnings surprise, our test set-up also addresses the possibility that earnings surprises may proxy for stronger future economic fundamentals. A violation of the identification assumption would not only require an unobservable time-varying characteristic that independently predicts the outcome, but also a discontinuity in such a characteristic.

Because the census data is limited to manufacturing firms and thus more limited than the sample in Almeida et al. (2016), we begin by verifying whether there is a discontinuity in the level of repurchases around the zero pre-repurchase EPS surprise threshold which also holds in the subsample of manufacturing firms. To do so, we estimate equation (2) with Repurchases $_{i t}$ as an outcome variable. Repurchases $i t$ are dollars of accretive repurchases, normalized by lagged assets. ${ }^{4}$

Table A.1 and Figure A.1 in the Appendix show that the relation between the discontinuity in the pre-repurchase EPS and doing additional buybacks is strong. That is, firms engage in significant additional buybacks if they would have missed their earnings estimates absent such buybacks.

In section 5, we will further show that firms that fall just to the right and the left of

\footnotetext{
${ }^{4}$ Net repurchases are measured following Fama and French $(2001)$, i.e., as the increase in common Treasury stock if Treasury stock is not zero or missing. If Treasury stock is zero in the current and prior quarter, we measure repurchases as the difference between stock purchases and stock issuances from the statement of cash flows. If either of these amounts is negative, repurchases are set to zero. We define an accretive share repurchase as a repurchase that increases the EPS by at least one cent, following Hribar et al. (2006).
} 
the pre-repurchase EPS surprise display similar characteristics and trends. This supports

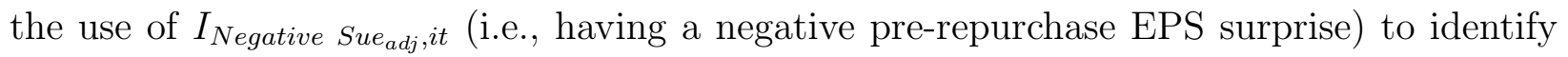
the effect of the incentive to engage in repurchases on firms' future outcomes using a fuzzy regression discontinuity $(\mathrm{RD})$ framework.

\section{Results}

This section estimates the effect of incentives to invest resources in boosting short-term performance measures on firms' resource allocation and productivity, employing a fuzzy regression discontinuity $(\mathrm{RD})$ framework described in the previous section.

\subsection{Main findings}

We begin the analysis from estimating regression 2 using firm-level data on investment and employment. The results are reported in Panel A of Table II. We find that firms that have incentives to spend resources on repurchases to boost EPS cut investments and reduce employment expenditures. Specifically, cuts in employment and investment correspond to $10 \%$ and $8 \%$ of the mean employment and capital expenditures in our sample, respectively. Panel B of Table II shows that we obtain very similar results using plant-level data. We observe cuts in investment and employment for firms that have incentives to invest resources in boosting short-term performance measures. For instance, plants invest on average 0.049\% of capital stock less in capital expenditures, which represents around $5 \%$ of mean plantlevel capital expenditures. Overall, both firm-level and plant-level results are consistent with Almeida et al. (2016) and suggest that firms' incentives to spend resources on stock repurchases in order to boost EPS lead to changes in resource allocation.

[Insert Table II here] 
We next consider the relation between $I_{\text {Negative }_{\text {Sue }}}$ and changes in TFP $(\Delta T F P)$. $\triangle T F P$ is the difference between the three-year average future productivity of plant $j$ in firm $i$ and the lagged productivity of that plant. When we use firm-level data, $\triangle T F P$ is the average change in TFP across a firm's plants. The estimates are report in Table III.

[Insert Table III here]

We find that firms with stronger incentives to engage in EPS-driven repurchases experience a significant deterioration in productivity. Specifically, firm- and plant-level productivity fall by $1.4 \%$ and $1.2 \%$, respectively. Overall, we find that stronger incentives to boost short-term performance (as measured by EPS) lead to cuts in investments and employment as well as a drop at firm-level productivity.

One of the key advantages of using plant-level data is that we can study whether cuts in investment and employment depend on the plant's productivity. If any cuts in investment and employment primarily take place in less productive plants that suggest that the allocation of resources within firms is relatively efficient even in the light of short-termist incentives. In contrast, if cuts take place also in productive plants that would be consistent with relatively less efficient allocation of resources that are driven by such short-termist incentives. To address this question, we estimate regression eq:main using plant-level data and interact $I_{\text {Negative }_{\text {Sue }}}$ wij with two indicator variables, Productive $e_{t-1}$ and Unproductive $_{t-1}$. Productive $_{t-1}$ is a dummy variable equal to one if the plant has an above-median withinfirm total factor productivity in the year before the repurchases. Unproductive $t_{t-1}$ is defined analogously.

The results are reported in Table IV] Column 1 shows that cuts in employment are stronger for unproductive plants than for productive plants. On average, unproductive plants experience approximately 2.5 times more cuts than productive ones. This result is indicative of efficient allocation of cuts in labor resources across plants. However, in 
contrast to employment decisions, column 2 reveals that firms cut investment uniformly across productive and unproductive plants.

[Insert Table IV here]

\subsection{The dynamics of the consequences for productivity and re- source allocation}

In Table V, we next examine the dynamic progression of the measured effects. Our main results examine the average productivity and growth in employment and investment over a three-year period compared to the year before the incentive to engage in EPS-driven repurchases. However, we would expect especially changes to productivity to not be immediate, but instead may take some time to show up strongly in the data, and similarly, the significant cuts to employment and investment that we find may also not be immediate as firms may react with some lag, for example, due to frictions that make it difficult to make immediate cuts to such investments.

$$
\text { [Insert Table } \mathrm{V} \text { here] }
$$

Panel A of Table $\mathrm{V}$ studies the dynamics of these effects at the firm-level. The results show that these effects indeed grow over time over each of the three years that we examine. In particular, the productivity effects increase from a change of around -0.011 in the first year, to -0.017 in the third year; that is, the effect on productivity grows by an additional $55 \%$ percent $(-0.017-(-0.011)) /(-0.011)$ when we look beyond just the first year. We observe broadly similar effects for employment and investment. For employment, the effect grows every year, consistent with high adjustment costs of labor. For investments, the bulk of the effect is the first year, and the additional impact of the second and third year are relatively smaller. 
In Panel B of Table $\mathrm{V}$, we examine these effects at the plant-level, where we further can interact these effects by whether a plant is productive or not. The table shows that the effects for both employment grow every year, both for production and non-production workers. For investment, the cuts to productive plants represents the most immediate effects, whereas the cuts to unproductive plants take time. This latter result is consistent with our previous results showing that it seems that the long-run cuts to investments appear particularly inefficient when firms are faced with short-term pressures to manage EPS, as the productive plants get cuts just as much as the unproductive plants, and further, these productive plants also experience these cuts sooner.

\section{Cross-sectional Heterogeneity}

\subsection{Right-to-Work States}

In this section, we investigate whether cuts in employment and investment are similar in states that have and have not adopted right-to-work (RTW) legislation. Labor unions often criticize firms for been short-term oriented. On the other hand, labor unions may themselves act as an impediment to doing relatively more efficient cuts, to the extent that labor rules constrain a firm's actions. Therefore, it is interesting to see whether companies that have strong incentives to boost short-term measures of performance engage in a more efficient allocation of resources when the labor force is more organized. For this analysis, we consider two sub-samples of plants: plants located in states that have adopted RTW legislation and plants located in states that have not adopted RTW legislation. The results are reported in table VI,

[Insert Table VI here]

Panel A reports the results for employment and investment. We observe striking dif- 
ferences in firms' responses to incentives to repurchase shares based on the level of labor unionization. Columns 1 and 2 show that for plants located in RTW states-where the labor force is less organized - the only significant cuts are observed for employment in unproductive units. We do not find significant cuts in investment across any type of plant. Moreover, we find no significant changes in employment in productive plants. Thus, our findings indicate that firms that are located in RTW states respond efficiently to the pressure to boost measures of short-term performance. We observe very different responses for plants located in non-RTW states. Columns 3 and 4 in Table VI show that these firms experience significant cuts in employment not only for unproductive plants but also for productive plants. Moreover, we find significant cuts in investment across all types of plants.

Since labor unionization is more likely to cover production workers, we next investigate whether changes in employment are similar for production and non-production workers. Table VII reports the results for changes in employment for production and non-production workers. Production workers are employees (up through the working foreman level) engaged in production operations at the plant. Non-production personnel includes supervisors (above the working foreman level) and office employees in sales and marketing, financing, purchasing, professional and technical.

\section{[Insert Table VII here]}

Columns 1 and 2 show that for plants located in RTW states, the significant cuts in employment are observed for all types of employees in unproductive units. For plants located in non-RTW states, cuts in production employees are weaker for productive plants, supporting the protection granted by unionization. In contrast, we find that firms cut non-production employees in productive and non-productive plants. These results indicate that unionization shields production workers from layoffs. However, there are spillover effects from this on non-production workers as we observe more inefficient cuts in the employment of these 
non-production workers that take place also in productive plants.

Overall, our findings suggest that plants located in non-RTW states experience less efficient cuts than plants located in RTW states, indicating that union power adversely affects the reallocation of resources. The key question, of course, whether these differences in the reallocation of resources ultimately lead to changes in productivity. Panel B in Table VI sheds light on this question. In this table, we investigate whether the unconditional changes in firm-level productivity depend on the fraction of the firm's business located in RTW states. We measure a firm's exposure to RTW states using the fraction of plants located in RTW states as well as the fraction of employees located in RTW states. We then allocate firms into two groups based on whether their exposure to RTW states is above or below the sample median.

Panel B in Table VI reports the results. The results support our conjecture that firms with stronger labor unions undertake less efficient cuts and consequently experience significant deterioration in firm productivity. These firms, therefore, are likely cutting positive NPV projects. In contrast, firms with weaker labor unions undertake efficient cuts and consequently experience no significant deterioration in firm productivity.

\subsection{The Role of explicit EPS incentives}

The incentive to manage EPS importantly differs across firms, where some firms may care a lot about EPS and others not as much. This, in turn, has consequences for how these firms react when faced with a short-term incentive to boost EPS using share repurchases. Almeida et al. (2016) show that firms that firms that explicitly mention "EPS" in their annual proxy statement make significantly larger buybacks when they would otherwise just miss their EPS target; consequently, these firms also make larger firm-level cuts to employment

and investment. By contast, firms that do not mention "EPS" tend to not engage in as much buyback activity to manage their EPS, and consequently also make smaller cuts to 
employment and investment.

In this section, we build on this insight to study how the effects on producity and resource allocation differs across firms who have different incentives to care about EPS. Specifically, our measure for whether a firm cares about EPS follows Almeida et al. (2016) and is based on whether a firm's proxy statement (Form DEF-14A) mentions the words "EPS" or "Earnings Per Share". We create this measure by using a script that searches through proxy statements looking for these words; we then match these proxy filings to our sample based on CIK code and year. Similarly to the previous section, we then split our sample and run the regressions similar to IV in subsamples that are based on whether the firm mentions EPS or not in the proxy statement.

\section{[Insert Table VIII here]}

In Panel A of Table VIII, we find that the cuts appear to be significantly less efficient among the firms where managers have a special incentive to focus on EPS - these were notably also the firms that react more strongly buy doing larger repurchases. In particular, these firms cut employment virtually equally across both productive and unproductive plants, and cut investment more in the relatively more productive plants. On the other hand, the firms that do not mention EPS, and thus do not make as large buybacks, appear to do cuts that are much smaller and also more efficient, as these firms cut both employment and investment more in their unproductive plants.

In Panel B of Table VIII, we next examine whether the resulting productivity consequences differ between firms that mention EPS vs. those that do not when faced with an incentive to use repurchases to meet their EPS target. The results show that the negative consequences for TFP are concentrated only in those firms that mention EPS. Conversely, among the firms that do not mention EPS, there is no evidence of adverse consequences. This is consistent with these latter firms not caring as much about using buybacks to meet 
their EPS numbers, and thus making smaller cuts that are only concentrated in the underperforming cuts. By contrast, the firms that care more about EPS make more substantial cuts in aggregate that are in turn less discriminate and therefore negatively affect also these firms' productive plants.

\section{Robustness}

In this section, we discuss several robustness tests for our results.

We first examine the extent to which our results could be sensitivity to alternative ways of measuring our key variables. Panels A and B of Table IX shows first that our baseline results from Tables $\mathrm{II}$ and $\mathrm{III}$ are robust to alternative measures of changes to productivity and resource allociation. While our baseline results are based on changes to TFP, these alternative measures include changes in operating margin. We also find that our results for productivity (TFP) continue to hold if examine changes to labor and capital productivity separately, where these measures are defined as described in section 2.1 .

Table IX further shows that the baseline cuts in investments when firms are faced with an incentive to engage in EPS-driven buybacks continues to hold if we limit the investments to those in only machinery (column 4). Similarly, our results on employment are similar if we examine change in log employment (rather than employment scaled by lagged capital as in the baseline results), or if we use a symmetric employment growth measure. ${ }^{5}$ Further, these results with alternative measures hold both at the firm-level (Panel A) and the plant-level (Panel B).

In Panel $\mathrm{C}$ of Table IX we re-examine the results from Table IV using alternative ways of defining the splits between productive and unproductive plants. In Columns (1) and (3)

\footnotetext{
${ }^{5}$ The symmetric growth rate of employment is calculated by dividing the three-year average change in the number of employees by the average of this change and lagged number of employees. This measure accommodates both entry and exit as well as limiting the effects of extreme values (Davis et al., 1998).
} 
we use a within-industry split on productivity, and in Columns (2) and (4), we use a split on within-firm marginal productivity of labor and within-firm return on capital for our results on changes to labor and investments, respectively. ${ }^{6}$ The results are very similar to the baseline results: We observe significant cuts to employment, but nevertheless relatively larger cuts in the less productive plants. On the other hand, cuts to investment is less discriminative across plants with different levels of productivity, and the productive plants experience just as large cuts as the unproductive plants.

Table $\mathrm{X}$ presents several robustness tests for our regression discontinuity structure. Panel A shows that our baseline results from Tables II and III are not sensitive to a smaller bandwidth, or to using a third-degree polynomial control for the level of the pre-repurchase EPS surprise.

Panel B of Table $\mathrm{X}$ further shows that firms in our sample that fall on either side of the pre-repurchase EPS surprise are similar to each other in the period before the event quarter, i.e., they follow parallel trends, which is consistent with our main identification assumption as was discussed in section 2.2. This supports the use of the regression discontinuity framework. Specifically, we find no systematic pre-existing differences in either the change in or the level of productivity or changes to or the level of labor or capital expenditures on either side of the zero pre-repurchase EPS threshold.

Finally, to further support the parallel trends assumption, and as a type of "placebo" test, Panel $\mathrm{C}$ in Table VI reports results where we consider defining the "negative pre-repurchase EPS" shock shifter by three years. That is, we assume a firm was treated three years before it actually was and study changes to resource allocation and productivity for productive and unproductive plants in a manner similar to table $\mathrm{VI}$. We find no results around this placebo event, consistent with our identification assumption of parallel trends.

\footnotetext{
${ }^{6}$ This compares to our use of a within-firm split on productivity in our baseline results in Table IV.
} 


\section{Conclusion}

In this paper we study the long-term effects of the incentive to engage in repurchases in order to meet short-term performance targets (EPS-driven repurchases). We do so using census data, which allows us to examine changes in resource allocation and productivity at the plant level, and study how pre-existing plant characteristics correlate with these changes.

Our evidence suggests that short term incentives lead to lower long-term productivity, but only if there are additional frictions that prevent firms from downsizing in an efficient manner. Firms that have incentives to engage in repurchases to meet EPS forecasts subsequently reduce investment and employment. If firms have most of their plants in states in which labor is weak, the bulk of the adjustment happens in unproductive plants, which minimizes the impact of the downsizing on productivity. But if their plants are located in states in which labor is strong, unionization of the labor force prevents firms from efficiently downsizing. These firms make cuts across the board, even in productive plants. As a result of this adjustment, productivity goes down in the long run.

Our main contribution is to provide a novel measure of the long-term consequences of short-term incentives, that focuses on within-firm reallocation of capital and labor. We focus on short-term incentives to conduct stock repurchases. In future research, it would be interesting to focus on other actions that have been suggested to indicate short-termism, such as an increase in the volatility of R\&D (Terry, 2017), or investment cuts due to vesting equity Edmans et al. (2017); Ladika and Sautner (2018). While we focus on frictions arising from unionization, other frictions may also be important to understand the long-term effects of short-term incentives. That is another promising avenue for future literature. 


\section{References}

Almeida, Heitor, Vyacheslav Fos, and Mathias Kronlund, 2016, The real effects of share repurchases, Journal of Financial Economics 119, 168 - 185.

Bebchuk, Lucian A, Alon Brav, and Wei Jiang, 2015, The long-term effects of hedge funds activism, Colum. L. Rev. 115, 1085.

Brav, Alon, Wei Jiang, and Hyunseob Kim, 2015, The real effects of hedge fund activism: Productivity, asset allocation, and labor outcomes, The Review of Financial Studies 28, $2723-2769$.

Brav, Alon, Wei Jiang, Song Ma, and Xuan Tian, 2018, How does hedge fund activism reshape corporate innovation?, Journal of Financial Economics 130, 237-264.

Chava, Sudheer, Andras Danis, and Alex Hsu, 2018, The impact of right-to-work laws on worker wages: Evidence from collective bargaining agreements, Working Paper.

Davis, Steven J, John C Haltiwanger, Scott Schuh, et al., 1998, Job creation and destruction, MIT Press Books 1.

Edmans, Alex, Vivian W Fang, and Katharina A Lewellen, 2017, Equity vesting and investment, The Review of Financial Studies 30, 2229-2271.

Ersahin, Nuri, 2018, Creditor rights, technology adoption, and productivity: Plant-level evidence, Working Paper.

Fama, Eugene F, and Kenneth R French, 2001, Disappearing dividends: changing firm characteristics or lower propensity to pay?, Journal of Financial Economics 60, 3-43.

Foster, Lucia, Cheryl Grim, and John Haltiwanger, 2016, Reallocation in the great recession: Cleansing or not?, Journal of Labor Economics 34, S293-S331. 
Graham, John R, Campbell R Harvey, and Shiva Rajgopal, 2005, The economic implications of corporate financial reporting, Journal of accounting and economics 40, 3-73.

Hribar, Paul, Nicole Thorne Jenkins, and W. Bruce Johnson, 2006, Stock repurchases as an earnings management device, Journal of Accounting and Economics 41, 3-27.

Kaplan, Steven N, 2018, Are us companies too short-term oriented? some thoughts, Journal of Applied Corporate Finance 30, 8-18.

Ladika, Tomislav, and Zacharias Sautner, 2018, Managerial short-termism and investment: Evidence from accelerated option vesting, Available at SSRN 2286789 .

Philippon, Thomas, and German Gutierrez, 2017, Investment-less growth: An empirical investigation, Brookings Papers on Economic Activity 89-190.

Serfling, Matthew, 2016, Firing costs and capital structure decisions, Journal of Finance 71, $2239-2286$.

Terry, Stephen J., 2017, The macro impact of short-termism, Working Paper. 


\section{Table I \\ Summary statistics}

This table provides sample summary statistics. Panel A shows summary statistics split by whether the firm as a slightly negative (from -0.003 to 0$)$ or positive $(0$ to +0.003$)$ pre-repurchase earnings per share (EPS) surprise. The pre-repurchase earnings surprise is the difference between the repurchase-adjusted ("pre-repurchase") EPS and the median end-of-quarter EPS forecast, scaled by the end-of-quarter stock price. Panel B splits by the firm- and plant-level "exposure" to state-level right-to-work (RTW) laws. Here, firms are sorted according to whether or not they have an above-median number of plants located in RTW states. Plants are sorted according to whether they are or are not located in RTW states. The unit of observation is a firm-year and plant-year for firm-level and plant-level statistics, respectively. All variables are defined in Appendix A. The list of states adopting RTW laws are listed in Appendix B.

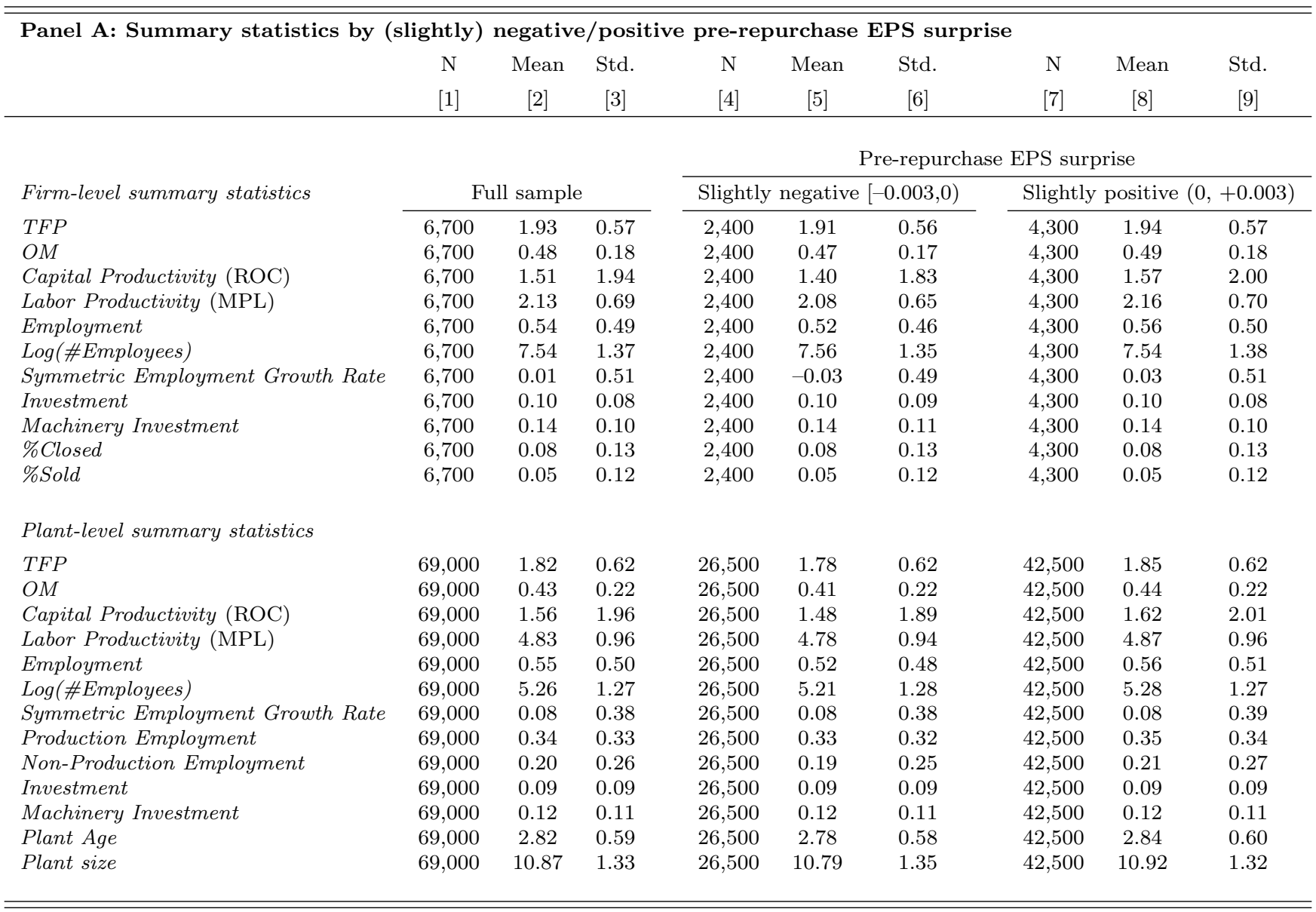




\begin{tabular}{|c|c|c|c|c|c|c|c|c|c|}
\hline \multicolumn{10}{|c|}{ Panel B: Summary statistics by exposure to right-to-work (RTW) laws } \\
\hline & $\mathrm{N}$ & Mean & Std. & $\mathrm{N}$ & Mean & Std. & $\mathrm{N}$ & Mean & Std. \\
\hline & [1] & {$[2]$} & {$[3]$} & [4] & {$[5]$} & {$[6]$} & {$[7]$} & [8] & {$[9]$} \\
\hline & & & & \multicolumn{6}{|c|}{ Presence in RTW states } \\
\hline Firm-level summary statistics & \multicolumn{3}{|c|}{ Full sample } & \multicolumn{3}{|c|}{$\begin{array}{l}\text { Above median } \% \text { of } \\
\text { plants in RTW states }\end{array}$} & \multicolumn{3}{|c|}{$\begin{array}{l}\text { Below median \% of } \\
\text { plants in RTW states }\end{array}$} \\
\hline TFP & 6,700 & 1.93 & 0.57 & 3,500 & 1.87 & 0.55 & 3,200 & 1.99 & 0.59 \\
\hline$O M$ & 6,700 & 0.48 & 0.18 & 3,500 & 0.46 & 0.17 & 3,200 & 0.51 & 0.19 \\
\hline Capital Productivity (ROC) & 6,700 & 1.51 & 1.94 & 3,500 & 1.48 & 2.00 & 3,200 & 1.55 & 1.88 \\
\hline Labor Productivity (MPL) & 6,700 & 2.13 & 0.69 & 3,500 & 2.06 & 0.62 & 3,200 & 2.20 & 0.75 \\
\hline Employment & 6,700 & 0.54 & 0.49 & 3,500 & 0.54 & 0.55 & 3,200 & 0.55 & 0.41 \\
\hline Log(\#Employees) & 6,700 & 7.54 & 1.37 & 3,500 & 7.73 & 1.40 & 3,200 & 7.34 & 1.31 \\
\hline Symmetric Employment Growth Rate & 6,700 & 0.01 & 0.51 & 3,500 & -0.01 & 0.50 & 3,200 & 0.03 & 0.52 \\
\hline Investment & 6,700 & 0.10 & 0.08 & 3,500 & 0.10 & 0.08 & 3,200 & 0.10 & 0.09 \\
\hline Machinery Investment & 6,700 & 0.14 & 0.10 & 3,500 & 0.13 & 0.09 & 3,200 & 0.14 & 0.11 \\
\hline Plant-level summary statistics & \multicolumn{3}{|c|}{ Full sample } & \multicolumn{3}{|c|}{ Plant in RTW state } & \multicolumn{3}{|c|}{ Plant in non-RTW state } \\
\hline TFP & 69,000 & 1.82 & 0.62 & 28,000 & 1.77 & 0.62 & 41,000 & 1.86 & 0.62 \\
\hline$O M$ & 69,000 & 0.43 & 0.22 & 28,000 & 0.40 & 0.22 & 41,000 & 0.44 & 0.21 \\
\hline Capital Productivity (ROC) & 69,000 & 1.56 & 1.96 & 28,000 & 1.58 & 2.03 & 41,000 & 1.55 & 1.92 \\
\hline Labor Productivity (MPL) & 69,000 & 4.83 & 0.96 & 28,000 & 4.78 & 1.03 & 41,000 & 4.87 & 0.90 \\
\hline Employment & 69,000 & 0.55 & 0.50 & 28,000 & 0.53 & 0.50 & 41,000 & 0.55 & 0.50 \\
\hline Log(\#Employees) & 69,000 & 5.26 & 1.27 & 28,000 & 5.28 & 1.27 & 41,000 & 5.24 & 1.27 \\
\hline Symmetric Employment Growth Rate & 69,000 & 0.08 & 0.38 & 28,000 & 0.09 & 0.38 & 41,000 & 0.07 & 0.38 \\
\hline Production Employment & 69,000 & 0.34 & 0.33 & 28,000 & 0.36 & 0.35 & 41,000 & 0.33 & 0.32 \\
\hline Non-Production Employment & 69,000 & 0.20 & 0.26 & 28,000 & 0.18 & 0.24 & 41,000 & 0.22 & 0.28 \\
\hline Investment & 69,000 & 0.09 & 0.09 & 28,000 & 0.09 & 0.09 & 41,000 & 0.09 & 0.09 \\
\hline Machinery Investment & 69,000 & 0.12 & 0.11 & 28,000 & 0.12 & 0.11 & 41,000 & 0.12 & 0.11 \\
\hline Plant Age & 69,000 & 2.82 & 0.59 & 28,000 & 2.79 & 0.61 & 41,000 & 2.84 & 0.58 \\
\hline Plant size & 69,000 & 10.87 & 1.33 & 28,000 & 10.90 & 1.34 & 41,000 & 10.85 & 1.33 \\
\hline
\end{tabular}




\section{Table II}

\section{Short-term incentives and resource allocation}

This table shows estimates of the impact of incentives to spend resources on short-term performance measures on resource allocation. In panel $\mathrm{A}$, the unit of observation in each regression is a firm-year pair. In panel $\mathrm{B}$, the unit of observation in each regression is a plant-year pair. The outcome variables are changes in employment expenditures and investment. Changes are measured as the difference from year before $(t-1)$ to the three year average (over $t+1$ to $t+3$ ) following the event year (year $t$ ) scaled by the capital stock in the year before. The pre-repurchase earnings surprise is the difference between the repurchase-adjusted ("pre-repurchase") EPS and the median end-of-quarter EPS forecast, scaled by the end-of-quarter stock price. These tests are conducted using only observations within a narrow window around the zero pre-repurchase EPS surprise threshold (between -0.003 and +0.003 ). All variables are defined in Appendix A. Standard errors (in parentheses) are clustered at the firm level. ${ }^{* * *},{ }^{*}$, and ${ }^{*}$ denote statistical significance at the $1 \%, 5 \%$, and $10 \%$ levels, respectively.

\begin{tabular}{lcc}
\hline \hline Panel A: Firm-level analysis & & \\
Dependent variable: & $\Delta$ Employment & $\Delta$ Investment \\
& {$[1]$} & {$[2]$} \\
\hline Negative Pre-Repurchase EPS Surprise & $-0.054^{* * *}$ & $-0.008^{* * *}$ \\
& $(0.015)$ & $(0.002)$ \\
\hline Year fixed effects & $\mathrm{Y}$ & $\mathrm{Y}$ \\
\hline Rounded $N$ & 6,700 & 6,700 \\
$R^{2}$ & 0.028 & 0.030 \\
\hline \hline & & \\
\hline \hline Panel B: Plant-level analysis & & \\
Dependent variable: & $\Delta$ Employment & $\Delta$ Investment \\
& {$[1]$} & {$[2]$} \\
\hline Negative Pre-Repurchase EPS Surprise & $-0.017^{* * *}$ & $-0.005^{* * *}$ \\
& $(0.004)$ & $(0.001)$ \\
\hline Linear control in pre-repurchase EPS surprise & $\mathrm{Y}$ & $\mathrm{Y}$ \\
Plant controls & $\mathrm{Y}$ & $\mathrm{Y}$ \\
Industry $\times$ year fixed effects & $\mathrm{Y}$ & $\mathrm{Y}$ \\
State $\times$ year fixed effects & $\mathrm{Y}$ & $\mathrm{Y}$ \\
\hline Rounded $N$ & 69,000 & 69,000 \\
$R^{2}$ & 0.146 & 0.073 \\
\hline \hline
\end{tabular}




\section{Table III \\ Short-term incentives and productivity}

This table shows estimates of impact of incentives to spend resources on short-term performance measures on firm and plant level productivity measures. In panel $\mathrm{A}$, the unit of observation in each regression is a firm-year pair. In panel $\mathrm{B}$, the unit of observation in each regression is a plant-year pair. The outcome variable is change in total factor productivity, measured as the difference from year before $(t-1)$ to the three year average (over $t+1$ to $t+3$ ) following the event year (year $t$ ) scaled by the capital stock in the year before. The pre-repurchase earnings surprise is the difference between the repurchase-adjusted ("pre-repurchase") EPS and the median end-of-quarter EPS forecast, scaled by the end-of-quarter stock price. These tests are conducted using only observations within a narrow window around the zero pre-repurchase EPS surprise threshold (between -0.003 and +0.003 ). Each column reports results including linear control in the pre-repurchase EPS surprise, interacted with the indicator of a negative pre-repurchase EPS surprise, firm or plant controls (age and size), and 4-digit NAICS industry-by-year and state-byyear fixed effects. All variables are defined in Appendix A. Standard errors (in parentheses) are clustered at the firm level. ***, **, and * denote statistical significance at the $1 \%, 5 \%$, and $10 \%$ levels, respectively.

\begin{tabular}{lcc}
\hline \hline Dependent variable: & \multicolumn{2}{c}{$\Delta T F P$} \\
Unit of observation: & firm-year & plant-year \\
& {$[1]$} & {$[2]$} \\
\hline Negative Pre-Repurchase EPS Surprise & $-0.014^{* *}$ & $-0.012^{* *}$ \\
& $(0.007)$ & $(0.004)$ \\
\hline Linear control in pre-repurchase EPS surprise & $\mathrm{N}$ & $\mathrm{Y}$ \\
Controls & $\mathrm{N}$ & $\mathrm{Y}$ \\
Industry $\times$ year fixed effects & $\mathrm{N}$ & $\mathrm{Y}$ \\
State $\times$ year fixed effects & $\mathrm{N}$ & $\mathrm{Y}$ \\
Year fixed effects & $\mathrm{Y}$ & $\mathrm{N}$ \\
\hline Rounded $N$ & 6,700 & 69,000 \\
$R^{2}$ & 0.011 & 0.115 \\
\hline \hline
\end{tabular}




\section{Table IV \\ Plant-level resource allocation effects by lagged plant productivity}

This table shows estimates of the plant-level impact of EPS-driven share repurchases on resource allocation among ex ante productive and unproductive plants. The unit of observation in each regression is a plant-year pair. The outcome variables are plant-level changes in employment expenditures and investment. Changes are measured as the difference from year before $(t-1)$ to the three year average (over $t+1$ to $t+3$ ) following the year of repurchases (year $t$ ) scaled by the capital stock in the year before. The pre-repurchase earnings surprise is the difference between the repurchase-adjusted ("pre-repurchase") EPS and the median end-of-quarter EPS forecast, scaled by the end-of-quarter stock price. Productive Pr-1 $_{t}$ is a dummy variable equal to one if the plant has an above-median within-firm total factor productivity in the year before the repurchases. Unproductive $_{t-1}$ is defined analogously. These tests are conducted using only observations within a narrow window around the zero pre-repurchase EPS surprise threshold (between -0.003 and $+0.003)$. Each column reports results including linear control in the pre-repurchase EPS surprise, interacted with the indicator of a negative pre-repurchase EPS surprise and the unproductive dummy variable, plant controls (age and size), and 4-digit NAICS industry-by-year and state-byyear fixed effects. All variables are defined in Appendix A. Standard errors (in parentheses) are clustered at the firm level. ${ }^{* *},{ }^{* *}$, and $*$ denote statistical significance at the $1 \%, 5 \%$, and $10 \%$ levels, respectively.

\begin{tabular}{lcc}
\hline \hline Dependent variable: & $\Delta$ Employment $^{-}$ & \multicolumn{2}{c}{ Investment } \\
& {$[1]$} & {$[2]$} \\
\hline Negative Pre-Repurchase EPS Surprise $\times$ Productive Pr-1 & $-0.008^{* *}$ & $-0.005^{* *}$ \\
& $(0.004)$ & $(0.002)$ \\
Negative Pre-Repurchase EPS Surprise $\times$ Unproductive $_{t-1}$ & $-0.022^{* * *}$ & $-0.004^{* *}$ \\
& $(0.005)$ & $(0.002)$ \\
Unproductive $t-1$ & $-0.014^{* * *}$ & $-0.003^{* *}$ \\
& $(0.004)$ & $(0.002)$ \\
\hline Linear control in pre-repurchase EPS surprise & $\mathrm{Y}$ & $\mathrm{Y}$ \\
Linear control in pre-repurchase EPS surprise $\times$ Unproductive $_{t-1}$ & $\mathrm{Y}$ & $\mathrm{Y}$ \\
Plant controls & $\mathrm{Y}$ & $\mathrm{Y}$ \\
Industry $\times$ year fixed effects & $\mathrm{Y}$ & $\mathrm{Y}$ \\
State $\times$ year fixed effects & $\mathrm{Y}$ & $\mathrm{Y}$ \\
\hline Rounded $N$ & 69,000 & 69,000 \\
$R^{2}$ & 0.145 & 0.073 \\
\hline \hline
\end{tabular}




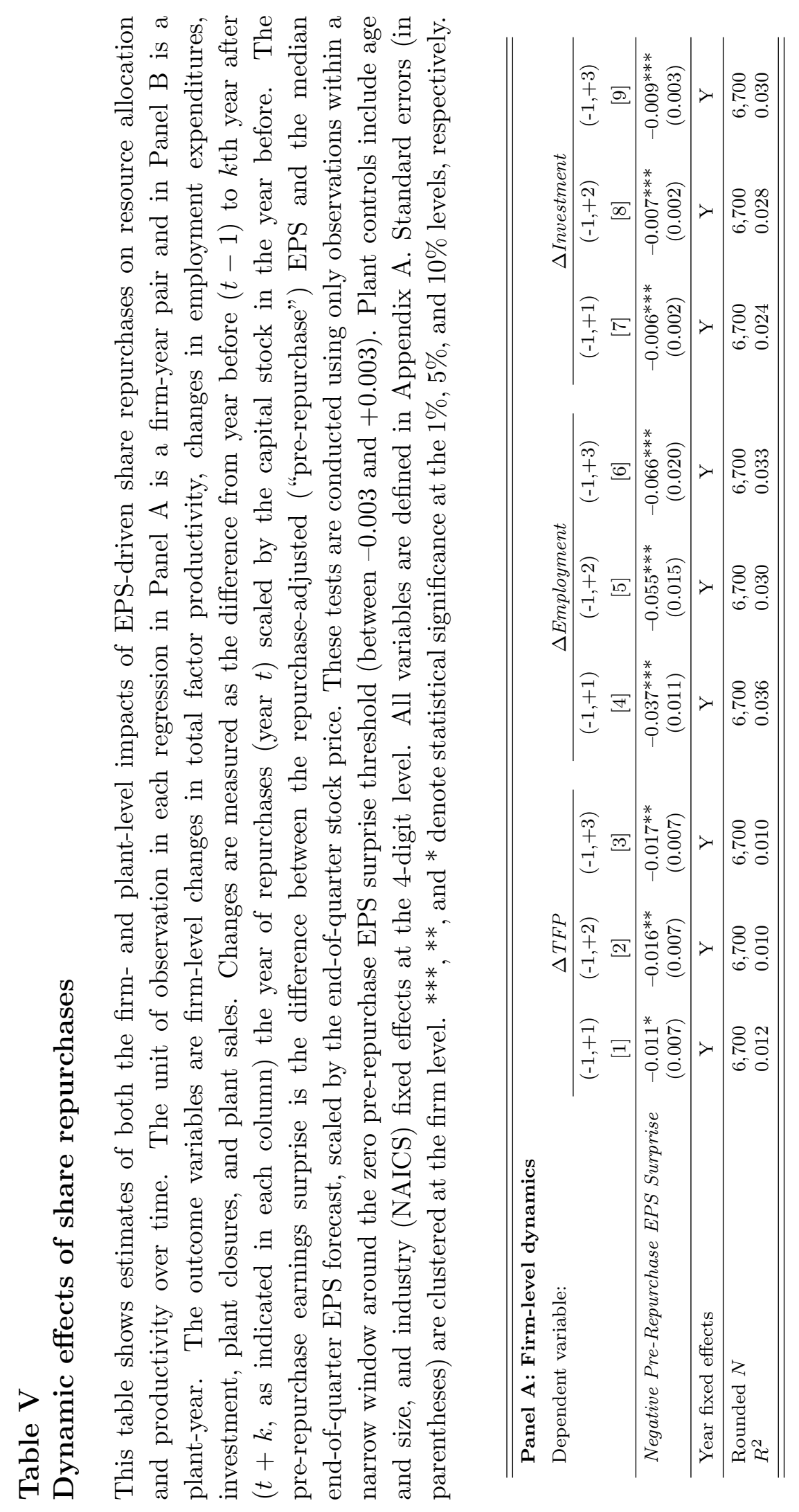




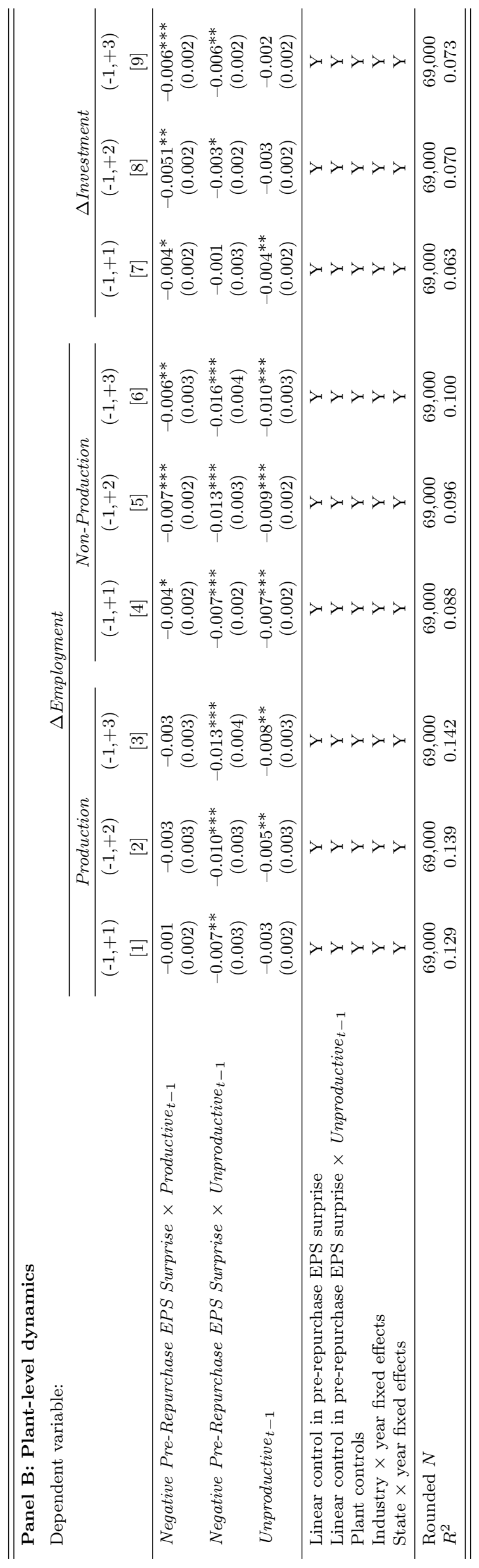




\section{Table VI State-level union power}

This table shows estimates of the plant-level impact of EPS-driven share repurchases on resource allocation and firm-level productivity at plants located in states that have and have not adopted right-to-work (RTW) legislation. In panel A, the unit of observation in each regression is a plant-year pair. The outcome variables are plant-level changes in employment expenditures and investment. Changes are measured as the difference from year before $(t-1)$ to the three year average (over $t+1$ to $t+3$ ) following the year of repurchases (year $t$ ) scaled by the capital stock in the year before. In panel B, the unit of observation in each regression is a firm-year pair. Firms are partitioned according to whether they have an above or below median share of plants (or number of employees) in states with RTW laws on the books. The outcome variable is the firm-level change in total factor productivity. This change is measured as the difference from year before $(t-1)$ to the three year average (over $t+1$ to $t+3$ ) following the year of repurchases (year $t$ ). The pre-repurchase earnings surprise is the difference between the repurchase-adjusted ("pre-repurchase") EPS and the median end-of-quarter EPS forecast, scaled by the end-of-quarter stock price. These tests are conducted using only observations within a narrow window around the zero pre-repurchase EPS surprise threshold (between -0.003 and +0.003). All variables are defined in Appendix A. The list of states adopting RTW laws are listed in Appendix B. Standard errors (in parentheses) are clustered at the firm level. ***,**, and $*$ denote statistical significance at the $1 \%, 5 \%$, and $10 \%$ levels, respectively.

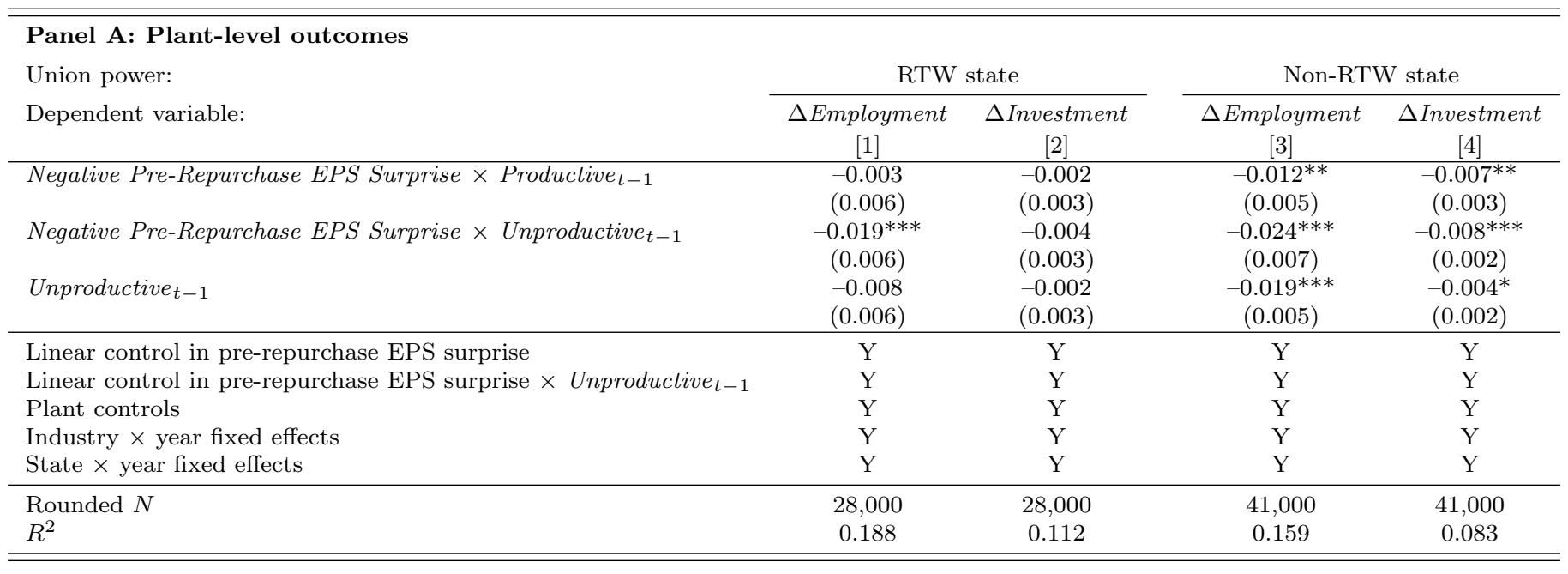

\begin{tabular}{|c|c|c|c|c|c|}
\hline \multicolumn{6}{|c|}{ Panel B: Firm-level productivity growth } \\
\hline \multicolumn{2}{|l|}{ Dependent variable: $\triangle T F P$} & \multicolumn{2}{|c|}{$\%$ plants in RTW states } & \multicolumn{2}{|c|}{ \% employees in RTW states } \\
\hline Firm splits: & $\begin{array}{c}\text { Average effect } \\
{[1]}\end{array}$ & $\begin{array}{c}\text { Above med. } \\
{[2]}\end{array}$ & $\begin{array}{c}\text { Below med. } \\
{[3]}\end{array}$ & $\begin{array}{c}\text { Above med. } \\
{[4]}\end{array}$ & $\begin{array}{c}\text { Below med. } \\
{[5]}\end{array}$ \\
\hline Negative Pre-Repurchase EPS Surprise & $\begin{array}{c}-0.014^{* *} \\
(0.007)\end{array}$ & $\begin{array}{l}-0.007 \\
(0.009)\end{array}$ & $\begin{array}{c}-0.023^{* *} \\
(0.011)\end{array}$ & $\begin{array}{l}-0.009 \\
(0.009)\end{array}$ & $\begin{array}{c}-0.020^{* *} \\
(0.010)\end{array}$ \\
\hline Year fixed effects & $\mathrm{Y}$ & $\mathrm{Y}$ & $\mathrm{Y}$ & $\mathrm{Y}$ & $\mathrm{Y}$ \\
\hline Rounded $N$ & 6,700 & 3,500 & 3,200 & 3,400 & 3,300 \\
\hline$R^{2}$ & 0.011 & 0.014 & 0.014 & 0.015 & 0.012 \\
\hline
\end{tabular}




\section{Table VII}

\section{Allocation effects by state-level union power: Employee type}

This table shows estimates of the plant-level impact of EPS-driven share repurchases on resource allocation at plants located in states that have and have not adopted right-to-work (RTW) legislation, while considering the role of employee type. The unit of observation in each regression is a plant-year pair. The outcome variables are plant-level changes in employment expenditures for production workers and non-production personnel. Changes are measured as the difference from year before $(t-1)$ to the three year average (over $t+1$ to $t+3$ ) following the year of repurchases (year $t$ ) scaled by the capital stock in the year before. Production workers are employees (up through the working foreman level) engaged in production operations at the plant. Non-production personnel include supervisors (above the working foreman level) and office employees in sales and marketing, financing, purchasing, professional and technical. The pre-repurchase earnings surprise is the difference between the repurchase-adjusted ("pre-repurchase") EPS and the median end-of-quarter EPS forecast, scaled by the end-of-quarter stock price. These tests are conducted using only observations within a narrow window around the zero pre-repurchase EPS surprise threshold (between -0.003 and +0.003 ). All variables are defined in Appendix A. The list of states adopting RTW laws are listed in Appendix B. Standard errors (in parentheses) are clustered at the firm level. ${ }^{* *},{ }^{* *}$, and $*$ denote statistical significance at the $1 \%, 5 \%$, and $10 \%$ levels, respectively.

\begin{tabular}{|c|c|c|c|c|}
\hline \multirow{2}{*}{$\begin{array}{l}\text { Dependent variable: } \Delta \text { Employment } \\
\text { Union power: } \\
\text { Employee type: }\end{array}$} & \multicolumn{2}{|c|}{ RTW state } & \multicolumn{2}{|c|}{ Non-RTW state } \\
\hline & $\begin{array}{l}\text { Prod. } \\
\text { [1] }\end{array}$ & $\begin{array}{l}\text { Non-Prod. } \\
{[2]}\end{array}$ & $\begin{array}{l}\text { Prod. } \\
{[4]}\end{array}$ & $\begin{array}{l}\text { Non-Prod. } \\
{[5]}\end{array}$ \\
\hline Negative Pre-Repurchase EPS Surprise $\times$ Productive $_{t-1}$ & $\begin{array}{c}0.000 \\
(0.004)\end{array}$ & $\begin{array}{l}-0.003 \\
(0.003)\end{array}$ & $\begin{array}{l}-0.004 \\
(0.004)\end{array}$ & $\begin{array}{c}-0.008^{* * *} \\
(0.003)\end{array}$ \\
\hline Negative Pre-Repurchase EPS Surprise $\times$ Unproductive $_{t-1}$ & $\begin{array}{c}-0.011^{* *} \\
(0.004)\end{array}$ & $\begin{array}{c}-0.008^{* *} \\
(0.004)\end{array}$ & $\begin{array}{c}-0.008^{*} \\
(0.004)\end{array}$ & $\begin{array}{c}-0.016^{* * *} \\
(0.004)\end{array}$ \\
\hline Unproductive $_{t-1}$ & $\begin{array}{c}0.000 \\
(0.004) \\
\end{array}$ & $\begin{array}{c}-0.009^{* *} \\
(0.003) \\
\end{array}$ & $\begin{array}{c}-0.010^{* * *} \\
(0.003) \\
\end{array}$ & $\begin{array}{c}-0.009^{* * *} \\
(0.003) \\
\end{array}$ \\
\hline Linear control in pre-repurchase EPS surprise & $\mathrm{Y}$ & $\mathrm{Y}$ & $\mathrm{Y}$ & $\mathrm{Y}$ \\
\hline Linear control in pre-repurchase EPS surprise $\times$ Unproductive $_{t-1}$ & $\mathrm{Y}$ & Y & $\mathrm{Y}$ & Y \\
\hline Plant controls & $\mathrm{Y}$ & $\mathrm{Y}$ & $\mathrm{Y}$ & $\mathrm{Y}$ \\
\hline Industry $\times$ year fixed effects & $\mathrm{Y}$ & $\mathrm{Y}$ & $\mathrm{Y}$ & $\mathrm{Y}$ \\
\hline State $\times$ year fixed effects & Y & $\mathrm{Y}$ & Y & $\mathrm{Y}$ \\
\hline Rounded $N$ & 28,000 & 28,000 & 41,000 & 41,000 \\
\hline$R^{2}$ & 0.189 & 0.136 & 0.156 & 0.117 \\
\hline
\end{tabular}




\section{Table VIII \\ Effects of share repurchases when EPS is mentioned in proxy statement}

This table shows estimates of the impacts of EPS-driven share repurchases on firm and plant outcomes depending on whether firms mention EPS in their proxy statement. In Panel A, the unit of observation in each regression is a plant-year pair. The outcome variables are plant-level changes in employment expenditures and investment. Changes are measured as the difference from year before $(t-1)$ to the three year average (over $t+1$ to $t+3$ ) following the year of repurchases (year $t$ ) scaled by the capital stock in the year before. The pre-repurchase earnings surprise is the difference between the repurchase-adjusted ("pre-repurchase") EPS and the median end-of-quarter EPS forecast, scaled by the end-of-quarter stock price. In Panel B, the unit of observation in each regression is a firm-year pair. Firms are partitioned according to whether they mention "EPS" or "Earnings Per Share" in their proxy statement. The outcome variable is the firm-level change in total factor productivity. This change is measured as the difference from year before $(t-1)$ to the three year average (over $t+1$ to $t+3$ ) following the year of repurchases (year $t$ ). These tests are conducted using only observations within a narrow window around the zero pre-repurchase EPS surprise threshold (between -0.003 and +0.003 ). All variables are defined in Appendix A. Standard errors (in parentheses) are clustered at the firm level. ***, **, and * denote statistical significance at the $1 \%, 5 \%$, and $10 \%$ levels, respectively.

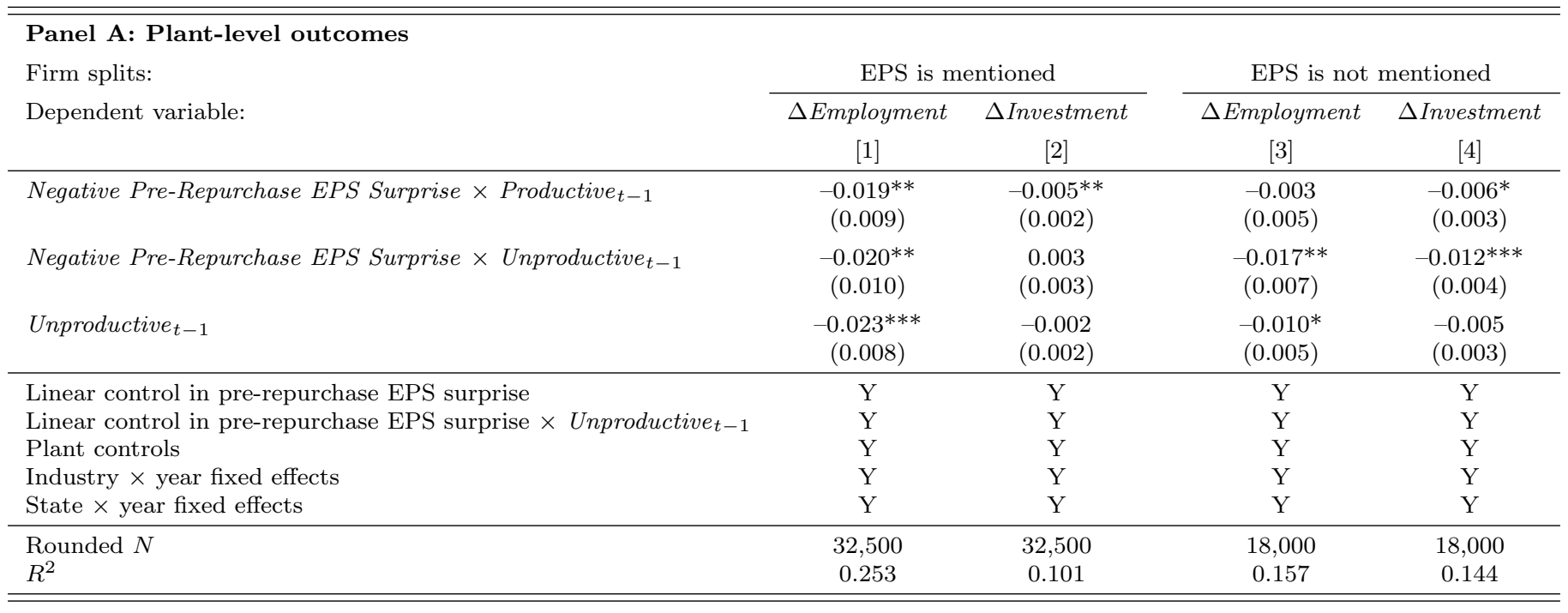

\begin{tabular}{lccc}
\hline \hline Panel B: Firm-level productivity growth & & \\
Dependent variable: $\triangle T F P$ & & \multicolumn{2}{c}{ EPS mentioned? } \\
\cline { 2 - 4 } Firm splits: & Average effect & Yes & No \\
& {$[1]$} & {$[2]$} & {$[3]$} \\
\hline Negative Pre-Repurchase EPS Surprise & $-0.016^{* *}$ & $-0.032^{* *}$ & -0.002 \\
& $(0.008)$ & $(0.013)$ & $(0.011)$ \\
\hline Year fixed effects & $\mathrm{Y}$ & $\mathrm{Y}$ & $\mathrm{Y}$ \\
\hline Rounded $N$ & 5,100 & 2,400 & 2,700 \\
$R^{2}$ & 0.011 & 0.015 & 0.010 \\
\hline \hline
\end{tabular}




\section{Table IX \\ Robustness checks: Alternative measurement of key variables}

This table considers alternative measurement when estimating the firm- and plant-level impacts of EPS-driven share repurchases on resource allocation. The unit of observation in each regression is either a firm- or plant-year pair. We examine alternative measures of productivity as outcome variables, including the operating margin, as well as labor and capital productivity. We also examine alternative measures of factor inputs, including machinery investments, the change in the $\log$ number of employees, and the symmetric employment growth. Panel $\mathrm{C}$ examines alternative measures of ex ante plant productivity, including the plant's within-industry (4-digit NAICS) TFP ranking, the within-firm labor productivity ranking, and the within-firm return on capital ranking. The pre-repurchase earnings surprise is the difference between the repurchase-adjusted ("pre-repurchase") EPS and the median end-of-quarter EPS forecast, scaled by the end-of-quarter stock price. These tests are conducted using only observations within a narrow window around the zero pre-repurchase EPS surprise threshold (between -0.003 and +0.003 ). Plant controls include age and size, and industry (NAICS) fixed effects at the 4-digit level. All variables are defined in Appendix A. Standard errors (in parentheses) are clustered at the firm level. ***, **, and ${ }^{*}$ denote statistical significance at the $1 \%, 5 \%$, and $10 \%$ levels, respectively.

\begin{tabular}{|c|c|c|c|c|c|c|}
\hline \multicolumn{7}{|c|}{ Panel A: Firm-level alternative measurement } \\
\hline \multirow{3}{*}{$\begin{array}{l}\text { Alternative outcome: } \\
\text { Dependent variable: }\end{array}$} & \multicolumn{3}{|c|}{ Productivity } & \multicolumn{3}{|c|}{ Factor inputs } \\
\hline & $\begin{array}{c}\Delta \text { Operating } \\
\text { Margin }\end{array}$ & $\begin{array}{c}\Delta \text { Labor } \\
\text { Prod. }\end{array}$ & $\begin{array}{c}\Delta \text { Capital } \\
\text { Prod. }\end{array}$ & $\begin{array}{l}\Delta \text { Machinery } \\
\text { Investments }\end{array}$ & $\begin{array}{c}\Delta \log ( \\
\# E m p .)\end{array}$ & $\begin{array}{l}\text { Symm. Emp. } \\
\text { Growth }\end{array}$ \\
\hline & {$[1]$} & {$[2]$} & {$[3]$} & {$[4]$} & {$[5]$} & {$[6]$} \\
\hline Negative Pre-Repurchase EPS Surprise & $\begin{array}{c}-0.007^{* * *} \\
(0.003)\end{array}$ & $\begin{array}{c}-0.022^{* *} \\
(0.009)\end{array}$ & $\begin{array}{c}-0.088^{* * *} \\
(0.029)\end{array}$ & $\begin{array}{c}-0.010^{* * *} \\
(0.003)\end{array}$ & $\begin{array}{c}-0.062^{* * *} \\
(0.015)\end{array}$ & $\begin{array}{c}-0.056^{* * *} \\
(0.013)\end{array}$ \\
\hline Year fixed effects & $\mathrm{Y}$ & $\mathrm{Y}$ & $\mathrm{Y}$ & $\mathrm{Y}$ & $\mathrm{Y}$ & $\mathrm{Y}$ \\
\hline Rounded $N$ & 6,700 & 6,700 & 6,700 & 6,700 & 6,700 & 6,700 \\
\hline$R^{2}$ & 0.010 & 0.010 & 0.017 & 0.028 & 0.056 & 0.061 \\
\hline
\end{tabular}

\begin{tabular}{|c|c|c|c|c|c|c|}
\hline \multicolumn{7}{|c|}{ Panel B: Plant-level alternative measurement } \\
\hline \multirow{3}{*}{$\begin{array}{l}\text { Alternative outcome: } \\
\text { Dependent variable: }\end{array}$} & \multicolumn{3}{|c|}{ Productivity } & \multicolumn{3}{|c|}{ Factor inputs } \\
\hline & $\begin{array}{c}\Delta \text { Operating } \\
\text { Margin }\end{array}$ & $\begin{array}{l}\Delta \text { Labor } \\
\text { Prod. }\end{array}$ & $\begin{array}{c}\Delta \text { Capital } \\
\text { Prod. }\end{array}$ & $\begin{array}{l}\Delta \text { Machinery } \\
\text { Investments }\end{array}$ & $\begin{array}{c}\Delta \log ( \\
\# E m p .)\end{array}$ & $\begin{array}{l}\text { Symm. Emp. } \\
\text { Growth }\end{array}$ \\
\hline & {$[1]$} & {$[2]$} & {$[3]$} & {$[4]$} & {$[5]$} & {$[6]$} \\
\hline Negative Pre-Repurchase EPS Surprise & $\begin{array}{c}-0.006^{* *} \\
(0.003)\end{array}$ & $\begin{array}{c}-0.010^{* *} \\
(0.005)\end{array}$ & $\begin{array}{c}-0.023^{* *} \\
(0.011)\end{array}$ & $\begin{array}{c}-0.003^{*} \\
(0.002)\end{array}$ & $\begin{array}{c}-0.015^{* * *} \\
(0.003)\end{array}$ & $\begin{array}{c}-0.024^{* * *} \\
(0.005)\end{array}$ \\
\hline Linear control in pre-repurchase EPS surprise & $\mathrm{Y}$ & $\mathrm{Y}$ & $\mathrm{Y}$ & $\mathrm{Y}$ & $\mathrm{Y}$ & $\mathrm{Y}$ \\
\hline Plant controls & $\mathrm{Y}$ & $\mathrm{Y}$ & Y & $\mathrm{Y}$ & $\mathrm{Y}$ & $\mathrm{Y}$ \\
\hline Industry $\times$ year fixed effects & $\mathrm{Y}$ & Y & $\mathrm{Y}$ & Y & $\mathrm{Y}$ & Y \\
\hline State $\times$ year fixed effects & $\mathrm{Y}$ & $\mathrm{Y}$ & $\mathrm{Y}$ & $\mathrm{Y}$ & $\mathrm{Y}$ & $\mathrm{Y}$ \\
\hline Rounded $N$ & 69,000 & 69,000 & 69,000 & 69,000 & 69,000 & 69,000 \\
\hline$R^{2}$ & 0.082 & 0.094 & 0.086 & 0.073 & 0.137 & 0.133 \\
\hline
\end{tabular}




\begin{tabular}{|c|c|c|c|c|}
\hline \multicolumn{5}{|c|}{ Panel C: Plant-level alternative measurement for productivity interaction } \\
\hline Dependent variable: & \multicolumn{2}{|c|}{$\Delta$ Employment } & \multicolumn{2}{|c|}{$\Delta$ Investment } \\
\hline Productivity definition used in interaction: & $\begin{array}{c}\text { Within- } \\
\text { ind. TFP } \\
{[1]}\end{array}$ & $\begin{array}{c}\text { Within- } \\
\text { firm MPL } \\
{[2]}\end{array}$ & $\begin{array}{c}\text { Within- } \\
\text { ind. TFP } \\
{[3]}\end{array}$ & $\begin{array}{c}\text { Within- } \\
\text { firm ROC } \\
{[4]}\end{array}$ \\
\hline Negative Pre-Repurchase EPS Surprise $\times$ Productive ${ }_{t-1}$ & $\begin{array}{c}-0.007^{* *} \\
(0.004)\end{array}$ & $\begin{array}{c}-0.009^{* *} \\
(0.004)\end{array}$ & $\begin{array}{c}-0.004^{* *} \\
(0.002)\end{array}$ & $\begin{array}{c}-0.005^{* * *} \\
(0.002)\end{array}$ \\
\hline Negative Pre-Repurchase EPS Surprise $\times$ Unproductive $_{t-1}$ & $\begin{array}{c}-0.018^{* * *} \\
(0.005)\end{array}$ & $\begin{array}{c}-0.018^{* * *} \\
(0.005)\end{array}$ & $\begin{array}{c}-0.003^{*} \\
(0.002)\end{array}$ & $\begin{array}{c}-0.003^{*} \\
(0.002)\end{array}$ \\
\hline Unproductive $_{t-1}$ & $\begin{array}{c}-0.018^{* * *} \\
(0.003)\end{array}$ & $\begin{array}{c}-0.018^{* * *} \\
(0.005)\end{array}$ & $\begin{array}{l}-0.002 \\
(0.001) \\
\end{array}$ & $\begin{array}{c}-0.012^{* * *} \\
(0.001)\end{array}$ \\
\hline Linear control in pre-repurchase EPS surprise & $\mathrm{Y}$ & Y & $\mathrm{Y}$ & $\mathrm{Y}$ \\
\hline Linear control in pre-repurchase EPS surprise $\times$ Unproductive $_{t-1}$ & Y & $\mathrm{Y}$ & Y & Y \\
\hline Plant controls & Y & Y & Y & Y \\
\hline Industry $\times$ year fixed effects & Y & Y & Y & $\mathrm{Y}$ \\
\hline State $\times$ year fixed effects & $\mathrm{Y}$ & $\mathrm{Y}$ & $\mathrm{Y}$ & $\mathrm{Y}$ \\
\hline Rounded $N$ & 69,000 & 69,000 & 69,000 & 69,000 \\
\hline$R^{2}$ & 0.148 & 0.148 & 0.073 & 0.074 \\
\hline
\end{tabular}




\section{Table X \\ Robustness checks: Specification and falsification tests}

This table conducts various specification checks for the impact of EPS-driven share repurchases on resource allocation and productivity. Panel A considers an alternative bandwidth around the zero pre-repurchase EPS surprise threshold, and a third-order polynomial for control in the pre-repurchase EPS surprise, which we interact with the indicator of a negative pre-repurchase EPS surprise. Panel B examines whether there are pre-existing trends in outcome variables. Panel $\mathrm{C}$ lags the timing of the negative pre-repurchase EPS surprises by three years. Outcome variables and the pre-repurchase earnings surprise are defined in previous tables. The pre-repurchase earnings surprise is the difference between the repurchase-adjusted ("pre-repurchase") EPS and the median end-of-quarter EPS forecast, scaled by the end-of-quarter stock price. These tests are conducted using only observations within a narrow window around the zero pre-repurchase EPS surprise threshold (between -0.003 and +0.003 ), except where indicated in Panel A. Plant controls include age and size, and industry (NAICS) fixed effects at the 4-digit level. All variables are defined in Appendix A. The list of states adopting RTW laws are listed in Appendix B. Standard errors (in parentheses) are clustered at the firm level. ***, **, and * denote statistical significance at the $1 \%, 5 \%$, and $10 \%$ levels, respectively.

\begin{tabular}{|c|c|c|c|c|c|c|}
\hline \multicolumn{7}{|l|}{ Panel A: RDD specification checks } \\
\hline Alternative specification choice: & \multicolumn{3}{|c|}{ Bandwidth selection $( \pm 0.001)$} & \multicolumn{3}{|c|}{ 3rd-degree polynomial } \\
\hline Dependent variable: & $\begin{array}{c}\triangle T F P \\
{[1]}\end{array}$ & $\begin{array}{c}\Delta \text { Employment } \\
{[2]}\end{array}$ & $\begin{array}{c}\Delta \text { Investment } \\
{[3]}\end{array}$ & $\begin{array}{c}\Delta T F P \\
{[4]}\end{array}$ & $\begin{array}{c}\Delta \text { Employment } \\
{[5]}\end{array}$ & $\begin{array}{c}\Delta \text { Investment } \\
{[6]}\end{array}$ \\
\hline Negative Pre-Repurchase EPS Surprise & $\begin{array}{c}-0.019^{* *} \\
(0.009)\end{array}$ & $\begin{array}{c}-0.057^{* * *} \\
(0.020)\end{array}$ & $\begin{array}{c}-0.008^{* * *} \\
(0.003)\end{array}$ & $\begin{array}{c}-0.015^{* *} \\
(0.007)\end{array}$ & $\begin{array}{c}-0.061^{* * *} \\
(0.016)\end{array}$ & $\begin{array}{c}-0.007^{* * *} \\
(0.002)\end{array}$ \\
\hline Year fixed effects & $\mathrm{Y}$ & $\mathrm{Y}$ & $\mathrm{Y}$ & $\mathrm{Y}$ & $\mathrm{Y}$ & $\mathrm{Y}$ \\
\hline $\begin{array}{l}\text { Rounded } N \\
R^{2}\end{array}$ & $\begin{array}{l}3,600 \\
0.011\end{array}$ & $\begin{array}{l}3,600 \\
0.024\end{array}$ & $\begin{array}{l}3,600 \\
0.036\end{array}$ & $\begin{array}{l}7,500 \\
0.011\end{array}$ & $\begin{array}{l}7,500 \\
0.030\end{array}$ & $\begin{array}{l}7,500 \\
0.029\end{array}$ \\
\hline \multicolumn{7}{|c|}{ Panel B: No pre-existing firm-level differences in key outcome variables } \\
\hline Differences in outcomes in: & \multicolumn{3}{|c|}{ Levels $(t-1)$} & \multicolumn{3}{|c|}{ Changes $(t-2$ to $t-1)$} \\
\hline Dependent variable: & $\begin{array}{c}\triangle T F P \\
{[1]}\end{array}$ & $\begin{array}{c}\Delta \text { Employment } \\
{[2]}\end{array}$ & $\begin{array}{c}\Delta \text { Investment } \\
{[3]}\end{array}$ & $\begin{array}{c}\Delta T F P \\
{[4]}\end{array}$ & $\begin{array}{c}\Delta \text { Employment } \\
{[5]}\end{array}$ & $\begin{array}{c}\Delta \text { Investment } \\
{[6]}\end{array}$ \\
\hline Negative Pre-Repurchase EPS Surprise & $\begin{array}{c}0.004 \\
(0.026)\end{array}$ & $\begin{array}{l}-0.004 \\
(0.045)\end{array}$ & $\begin{array}{l}-0.003 \\
(0.004)\end{array}$ & $\begin{array}{l}-0.001 \\
(0.012)\end{array}$ & $\begin{array}{l}-0.002 \\
(0.015)\end{array}$ & $\begin{array}{l}-0.003 \\
(0.003)\end{array}$ \\
\hline Year fixed effects & $\mathrm{Y}$ & $\mathrm{Y}$ & Y & Y & $\mathrm{Y}$ & $\mathrm{Y}$ \\
\hline $\begin{array}{l}\text { Rounded } N \\
R^{2}\end{array}$ & $\begin{array}{l}6,700 \\
0.028\end{array}$ & $\begin{array}{l}6,700 \\
0.007\end{array}$ & $\begin{array}{l}6,700 \\
0.018\end{array}$ & $\begin{array}{l}6,700 \\
0.011\end{array}$ & $\begin{array}{l}6,700 \\
0.051\end{array}$ & $\begin{array}{l}6,700 \\
0.019\end{array}$ \\
\hline
\end{tabular}




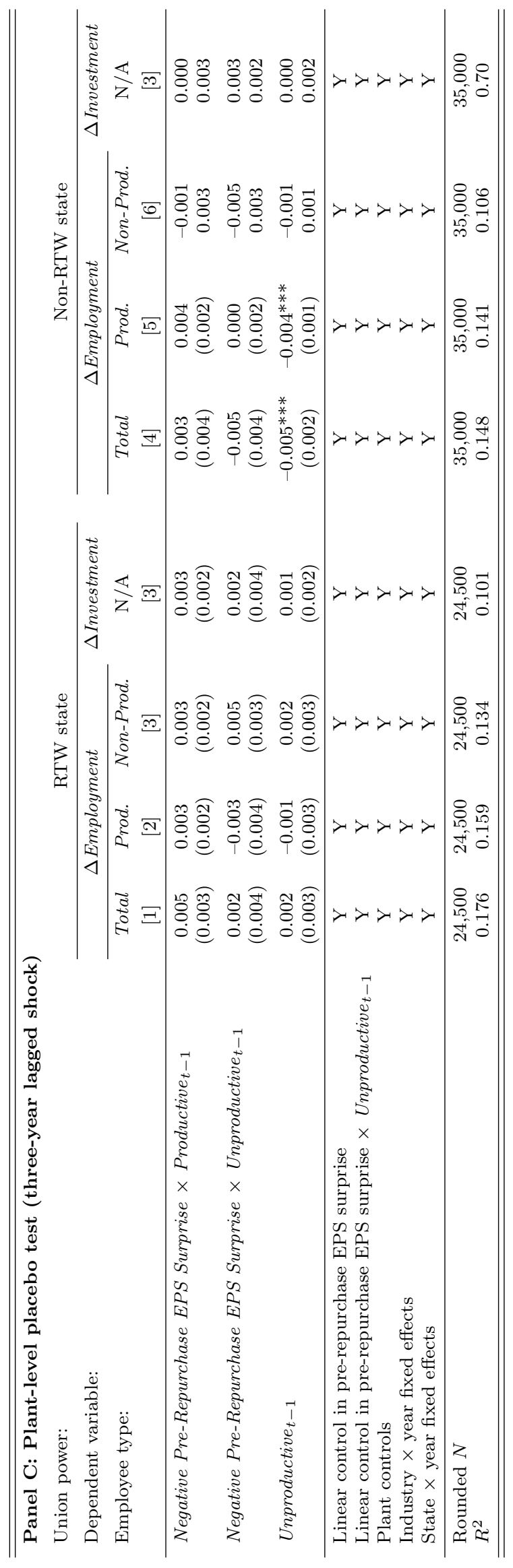




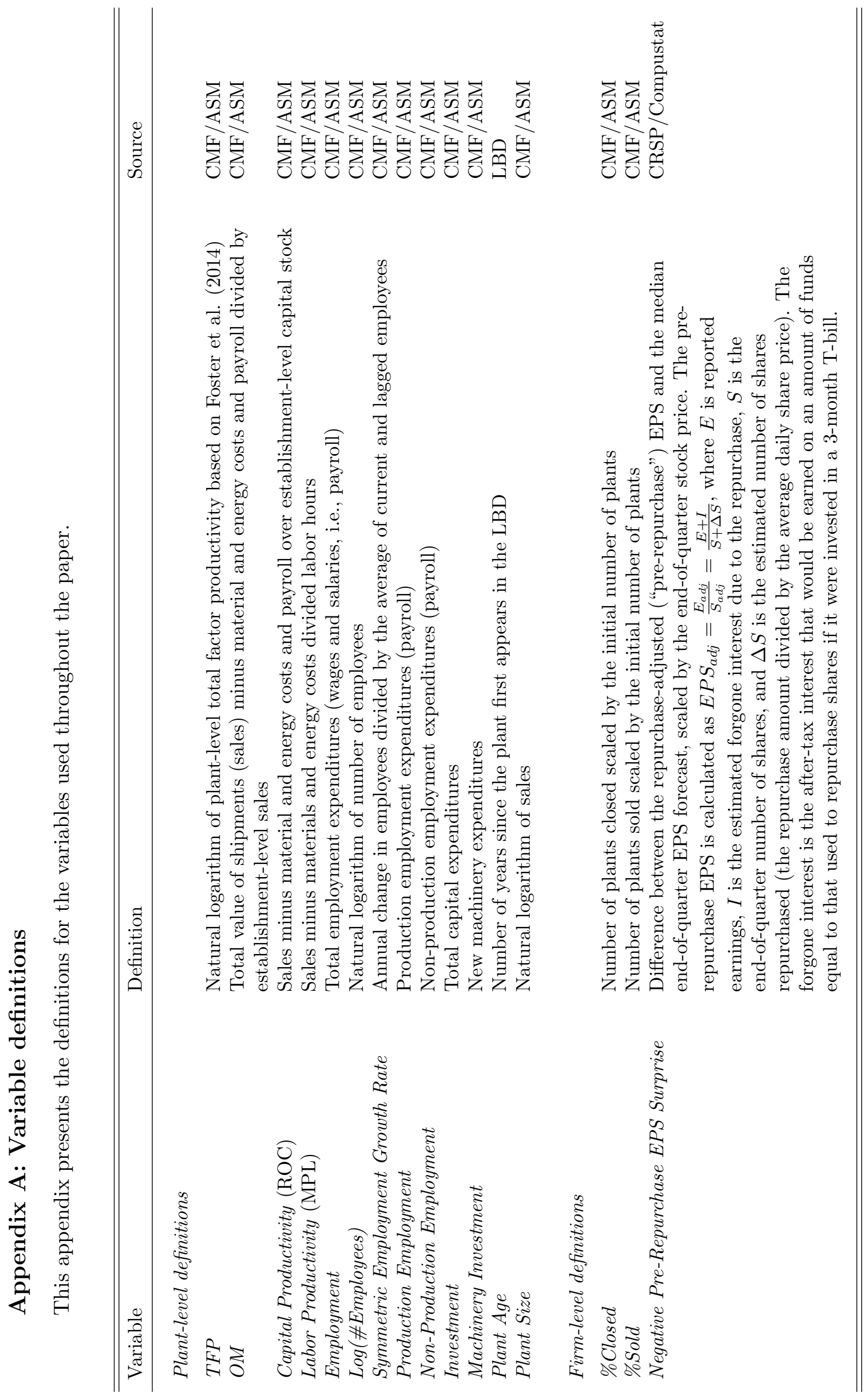




\section{Appendix B: Right-to-work (RTW) laws by state}

This table lists the effective year of adoption of right-to-work legislation either by the state constitution or by a statute. These data are provided in Chava et al. (2018).

\begin{tabular}{lc}
\hline \hline State & Adopted \\
\hline AL & 1953 \\
AK & \\
AZ & 1947 \\
AR & 1947 \\
CA & \\
CO & \\
CT & \\
DE & \\
DC & \\
FL & 1943 \\
GA & 1947 \\
HI & \\
ID & 1986 \\
IL & \\
IN & 2012 \\
IA & 1947 \\
KS & 1958 \\
KY & 2017 \\
LA & 1976 \\
ME & \\
MD & \\
MA & \\
MI & 2013 \\
MN & \\
MS & 1960 \\
MO & \\
MT & \\
NE & 1947 \\
NV & 1952 \\
NH & \\
NJ & \\
NM & \\
NY & \\
NC & 1947 \\
ND & 1947 \\
OH & \\
OK & 2001 \\
OR & \\
PA & \\
RI & \\
SC & 1954 \\
SD & 1947 \\
TN & 1947 \\
TX & 1947 \\
UT & 1955 \\
VT & \\
VA & 1947 \\
WA & \\
WV & 2016 \\
WI & 2015 \\
WY & 1963 \\
\hline \hline
\end{tabular}




\section{Figure A.1: Negative pre-repurchase EPS surprises and share repurchases among manufacturing firms}

This figure replicates results from Figure 1 in Almeida et al. (2016) within the sample of manufacturing firms. Manufacturing firms are defined as firms with 2-digit SIC codes between 20 and 39. The figure plots the probability of doing an accretive share repurchaseas a function of a prerepurchase earnings surprise. For every earnings surprise bin, the dots represent the probability of an accretive share repurchase - the fraction of firm-quarters with an accretive repurchase out of all firm-quarters in that bin. We define a share repurchase as accretive if it increases EPS by at least one cent. The pre-repurchase earnings surprise is the difference between the repurchase-adjusted ("pre-repurchase") earnings per share (EPS) and the median EPS forecast at the end of the quarter; this difference is normalized by the end-of-quarter stock price. The pre-repurchase EPS is calculated as follows: $E P S_{a d j}=E_{a d j} / S_{a d j}=(E+I) /(S+\Delta S)$, where $\mathrm{E}$ is reported earnings, I is the estimated forgone interest due to the repurchase, $\mathrm{S}$ is the number of shares at the end of the quarter, and $\Delta S$ is the estimated number of shares repurchased (the repurchase amount divided by the average daily share price). The forgone interest is the after-tax interest that would be earned on an amount of funds equal to that used to repurchase shares if it were instead invested in a 3-month T-bill.

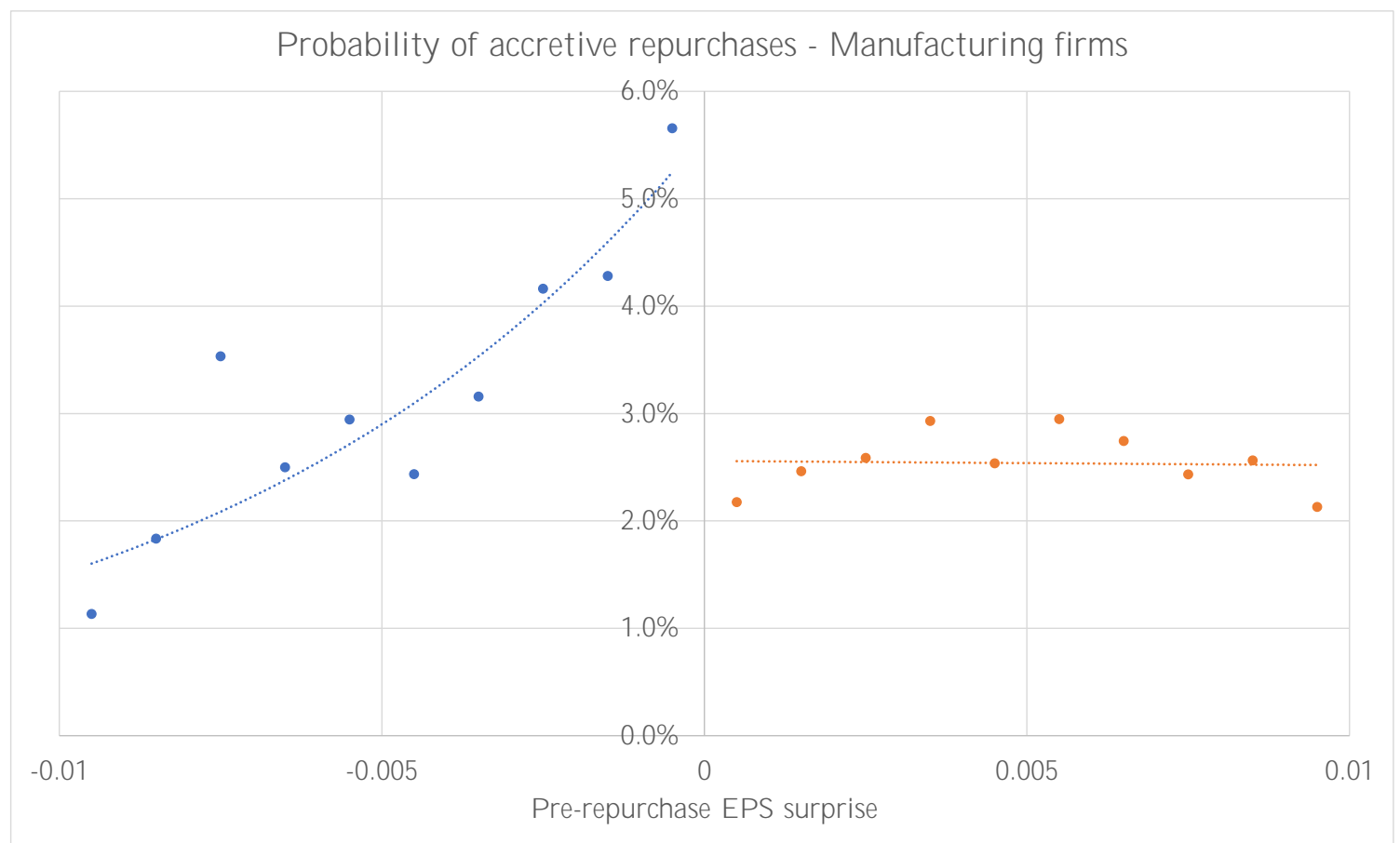




\section{Table A.1: Negative pre-repurchase EPS surprises and share repurchases among manufacturing firms}

This table replicates results from Table 3 in Almeida et al. (2016) within the sample of manufacturing firms. Manufacturing firms are defined as firms with 2-digit SIC codes between 20 and 39. The table reports the relationship between having a negative pre-repurchase EPS surprise and the probability of doing a share repurchase in a firm-quarter. The calculation of the pre-repurchase EPS surprise is as described in Fig. A.1. Share repurchases are measured as follows: We measure "Net repurchases" following Fama and French (2001), i.e., as the increase in common Treasury stock if Treasury stock is not zero or missing; if Treasury stock is zero in the current and prior quarter, we measure repurchases as the difference between stock purchases and stock issuances from the statement of cash flows. If either of these amounts is negative, repurchases are set to zero. The regressions control for the linear relation between the pre-repurchase EPS surprise and repurchases, interacted with the indicator of a negative pre-repurchase EPS surprise, as well as time (year-quarter) fixed effects. We limit the sample to firm-quarters that fall in a small window around the zero pre-repurchase EPS surprise threshold (with a pre-repurchase EPS surprise normalized by share price between -0.003 and 0.003). The dependent variable Column (1) is the amount of net repurchases, normalized by assets. The dependent variable in Column (2) is an indicator variable for whether the firm conducts an accretive share repurchase of at least one cent. t-Stats based on standard errors that are robust to heteroskedasticity and clustered at the firm level are reported in parentheses below the coefficient estimates. ${ }^{*}, * *$, And ${ }^{* * *}$ represent statistical significance at the 10

\begin{tabular}{lcc}
\hline \hline Dependent variable: & Net Repurchases & I[Accretive Repurchase] \\
& {$[1]$} & {$[2]$} \\
\hline Negative Pre-Repurchase EPS Surprise & $0.0036^{* * *}$ & $0.0458^{* * *}$ \\
& $(8.23)$ & $(7.09)$ \\
\hline Linear control in pre-repurchase EPS surprise & $\mathrm{Y}$ & $\mathrm{Y}$ \\
Year fixed effects & $\mathrm{Y}$ & $\mathrm{Y}$ \\
\hline Rounded $N$ & 23,443 & 23,587 \\
$R^{2}$ & 0.051 & 0.028 \\
\hline \hline
\end{tabular}

